\title{
Major element signatures of silicate dust deposited on the West African margin: links with transport patterns and provenance regions
}

Meryll Le Quilleuc ${ }^{1}$, Aloys Bory ${ }^{1 *}$, Sylvie Philippe ${ }^{1}$, Yevgeny Derimian ${ }^{2}$, Charlotte Skonieczny ${ }^{3}$, Jean- Eudes Petit $^{4}$, Déborah Ponlevé ${ }^{1}$, Aboubacry Diallo ${ }^{5}$, Thierno Ndiaye ${ }^{5}$, Véronique Alaimo ${ }^{6}$, Louis Quentin ${ }^{1}$, Nicolas Tribovillard ${ }^{1}$ and Viviane Bout-Roumazeilles ${ }^{1}$

\author{
${ }^{1}$ Univ. Lille, CNRS, Univ. Littoral Côte d'Opale, UMR 8187 - LOG - Laboratoire d'Océanologie et de \\ Géosciences, F-59000 Lille, France \\ ${ }^{2}$ Univ. Lille, CNRS, UMR 8518 - LOA - Laboratoire d'Optique Atmosphérique, F-59000 Lille, France ${ }^{3}$ Université \\ Paris-Saclay, CNRS, GEOPS, 91405, Orsay, France \\ ${ }^{4}$ Laboratoire des Sciences du Climat et de l'Environnement, UMR 8212, CEA/Orme des Merisiers, 91191 Gif- \\ sur-Yvette, France \\ ${ }^{5}$ IRD, US 191, IMAGO, Dakar, Senegal \\ ${ }^{6}$ Univ Lille, CNRS, UMR 8516 - LASIRE - LAboratoire de Spectroscopie pour les Interactions, la Réactivité et \\ I'Environnement, F-59000 Lille, France \\ *corresponding author
}

\begin{abstract}
Mineral dust deposition characteristics are poorly constrained, even in the North-eastern Tropical Atlantic Ocean, which is immediately downwind of the Saharan desert and the largest marine repository of aeolian dust in the world. Here we report on a 2-year (March 2013-February 2015) time- series of deposited dust on the Senegalese margin. This record enables us to document the chemical variability (major elements) of the settling Saharan dust $(<30 \mu \mathrm{m}$ silicate fraction, i.e. carbonate-free) at a resolution varying from one week to one day, along with the deposition flux. This continuous time-series reveals a greater geochemical diversity than previously reported, particularly during the dry winterspring season when continental trade winds sweep across vast regions of West Africa at low atmospheric levels before reaching the sampling site. By contrast, during major deposition events, which make up for most of the yearly flux, our record shows that Saharan dust chemical composition displays much narrower ranges. Trajectory analyses indicate that these relatively well-defined chemical signatures are due to the limited number of provenance sectors involved during major deposition occurrences. The chemical characterization of the dust deposited during these events hence allows identifying the major element fingerprint of the related source regions, the most important one being a sizeable area at the border of Algeria and Mali including the Tanezrouft desert north of the Taoudeni basin. Also, since these major events are associated with major Saharan outbreaks, they provide estimations of the prevailing elemental signatures for Saharan dust impacting the North-eastern Tropical Atlantic Ocean.
\end{abstract}

Keywords: Saharan dust, deposition flux, major elements, Senegal, Tropical Atlantic Ocean, back trajectography, dust sources, Tanezrouft desert

\section{Introduction}

The Sahara -currently the largest warm desert on Earth-is also by far the most important aeolian dust producer in the world (Yu et al., 2015). These aerosols consist of tiny mineral fragments within the silt and clay size range mainly (although coarser, sandy particles may also be present), that are the end products of various rock weathering processes (Muhs, 2013). Dust is injected in the atmosphere by the action of wind stress on bare surfaces (arid and semi-arid areas) within several meteorological contexts (Schepanski et al., 2009; Knippertz and Todd, 2012). It is estimated that the Saharan desert releases 
$\sim 180$ megatons of mineral particles in the northern hemisphere tropical and subtropical atmosphere every year (Yu et al., 2015). Saharan dust is often exported over long distances, predominantly across the Tropical North Atlantic Ocean by trade winds and mid-tropospheric jets (Chiapello et al., 1995).

During its atmospheric cycle, dust interferes with incoming and outgoing radiations (Arimoto et al., 2001). These mineral particles may also serve as condensation and ice nuclei (DeMott et al., 2003), impacting cloud formation and thus the hydrological cycle (Sokolik et al., 2001). Saharan dust therefore has direct and indirect effects on the radiative budget along its atmospheric pathway (Formenti et al., 2011). As a result, Saharan dust outbreaks also have an influence on ocean temperature, with potential consequences for cyclone generation in the Atlantic (Dunion \& Velden, 2003).

As it settles back to the Earth surfaces, mineral dust dispersal over oceans represents a net input of nutrients such as iron and phosphorus (Powell et al., 2015). Long-range dust transport therefore has a significant impact on the marine biogeochemistry, particularly in open-ocean areas depleted in nutrients, with possible consequence on the atmospheric $\mathrm{CO}_{2}$ drawdown through the biological pump (Moore and Braucher, 2008; Chien et al., 2016). Similarly, dust deposition over continental landmasses contributes to soil fertilization. It has been suggested that the Amazon forest, in particular, benefits from phosphorus inputs associated with Saharan dust deposits (Bristow et al., 2009). Dust may also represent a health hazard, both in or near source regions (De Longueville et al., 2010) and in remote locations impacted by long-range dust transport such as the Caribbean (Prospero et al., 1999).

Eventually, mineral dust accumulation in environmental archives has proved to be a useful proxy for past environmental reconstructions. Our knowledge of the West African climate evolution and the summer monsoon strength, for instance, is largely based on dust records retrieved both in the Mediterranean Sea and in the Northeastern Tropical Atlantic Ocean (Larrasoanã et al., 2003; Grant et al., 2017; Skonieczny et al., 2019). Overall, marine sediments and polar ice core records have shown there is an intimate relationship between climate evolution and dustiness during the Quaternary, both at low (Tiedemann et al., 1994) and high (Fuhrer et al., 1999) latitudes, bringing about a possible role of dust across climate transition through feedback processes (Lambert et al., 2015).

Dust properties and its impact on the environment and the climate system are principally contingent upon its mineral and chemical composition (Formenti et al., 2011). Considering the vastness of the Sahara-Sahel region, Saharan dust mineralogical and chemical composition is expected to vary across the desert (Moreno et al., 2006). In fact, this arid and semi-arid area stretches at present over a $\sim 4000 \mathrm{~km} x \sim 2000 \mathrm{~km}$ area from the Atlantic to the Red Sea and encompasses numerous dust emission "hotspots" (Prospero et al., 2002) spread over diverse geological settings (Linnemann et al., 2011). Yet, the existing database regarding dust mineral and chemical composition is rather thin (Chiapello et al., 1997; Caquineau et al., 2002; Formenti et al., 2011; Scheuvens et al., 2013). First, there is a rather poor geographical coverage, particularly in areas where dust emissions are the most intense, as revealed by satellite products (Prospero et al., 2002). Furthermore, when available, information on aeolian dust has generally been extracted from a few, discrete atmospheric samples, or relies on bulk sediment/soil material, which may not be identical to the composition of the fine aeolian material generated from these terrains. It is therefore unclear how representative these data are, spatially and temporally, with respect to both potential source areas and to dust exported long distance off West- Africa. Moreover, measured mineral/elements are frequently limited and both sampling and analytical protocols often differ between studies, complicating their comparison. Our knowledge of the Saharan dust composition variability is, as a result, largely incomplete (Scheuvens et al., 2013).

Here we report a 2-year times series of deposited Saharan dust chemical composition achieved at weekly or better temporal resolution on the Senegalese margin. Ten elements ( $\mathrm{Al}, \mathrm{Fe}, \mathrm{K}, \mathrm{Mg}, \mathrm{Ti}, \mathrm{Na}$, $\mathrm{Ca}$, $\mathrm{P}, \mathrm{Mn}$ and $\mathrm{Y}$ ) were analysed by ICP-OES on the $<30 \mu \mathrm{m}$ fraction of deposited dust after carbonate 
removal, in order to document the composition of the conservative, silicate fraction of the aerosol deposits. The sampling site, located under the major corridor of Saharan dust westward transport, is ideally situated for monitoring the chemical composition of the mineral dust exported to the Northeastern Tropical Atlantic. These chemical data complement earlier mineralogical measurements at this site (Skonieczny et al., 2011 and 2013) and allow advancing our comprehension of Saharan dust compositional variability. Back trajectographies were then computed to investigate the links between compositional changes and provenance regions, enabling us to differentiate the geochemical signatures range of some major source sectors. Improving our knowledge of the mineral and chemical composition of the dust transported to the Atlantic ocean and beyond in relation to its geographical origin within this vast arid and semi-arid region is in fact critical to track Saharan dust in the northern hemisphere atmosphere (Chiapello et al., 1997) and in environmental archives (Bory et al., 2002a), to interpret paleodust records (e.g., Colin et al., 2014), as well as to assess dust impact on marine and land biogeochemistry (Journet et al., 2008 ; Bristow et al., 2010). This knowledge will also benefit the recent development in remote sensing of airborne dust composition (Li et al., 2019) that rely on our understanding of dust mineralogical and chemical compositions and their relationships with aerosol optical properties (e.g., Lafon et al., 2006 ; Derimian et al., 2008).

\section{Materials and methods}

Dust was collected using a Capyr-type reversed pyramid-shaped passive PVC collector with an opening of $0.25 \mathrm{~m}^{2}$ (Goossens and Rajot, 2008) installed at about $10 \mathrm{~m}$ above ground on a dedicated tower made of scaffolding elements. This tower was set up on a vegetated dune facing the Atlantic Ocean on the premises of the Institut de la Recherche pour le Développement (IRD) ecological center in Mbour, Senegal. Vegetation is prevalent in the center and car traffic is minimal, reducing locally produced dust. All material in contact with the samples was made of plastic and acid-washed before use to minimize potential contamination with elements of interest. Total deposited dust (by dry and/or wet deposition processes) was retrieved by rinsing the walls of the collector with ultra-pure water $(\leq 500 \mathrm{ml})$ at weekly or better resolution; sampling resolution was increased to one day whenever it was possible, especially during major Saharan dust outbreaks that were forecasted by dust transport models (Westphal et al., 2009) and monitored by dust concentration measurements on the ground using a TEOM (Tapered element oscillating microbalance ; Marticorena et al., 2017; Marticorena, personal communication).

Samples were kept wet in sealed Nalgene polypropylene bottles until they were brought back to the University of Lille. Subsequent preparatory treatments before analyses were carried out within the clean lab facilities of the Laboratory of Oceanography \& Geosciences (LOG) using acid-cleaned vessels. After decantation, the supernatant water was syphoned out and samples were sieved with a $30 \mu \mathrm{m}$ nylon mesh in order to get rid of potential large vegetation debris and coarse mineral particles. In effect, although long range transport of giant mineral particles $(>75 \mu \mathrm{m})$ from the Saharan desert has recently been reported in the middle of the Atlantic (Van der Does et al., 2018) and also in Iceland (Varga et al., 2021), the bulk of long-range transported Saharan dust consist of particles <30 $\mu \mathrm{m}$ (Grousset et al., 1998; Stuut et al., 2005; Van der Does et al., 2016). Considering the rapid decrease of the grain size with distance to the sources (Pye, 1987; Van der Does et al., 2016), we therefore wanted to avoid giving excessive weight to the coarser fraction deposited at our coastal site (Skonieczny et al., 2011). Carbonates (and other soluble fractions such as sea salts), which may have already partly dissolved in the ultra-pure water used to collect the samples, were then removed using an acetic acid - sodium acetate buffer at $\mathrm{pH} \approx 4.5$. Working on the carbonate-free fraction has the primary advantage to allow the comparison of the results with sediment trap samples and marine sediments.

In fact, the latter are largely made of biogenic carbonates, which must therefore be removed in order to make possible geochemical analyses on the terrigenous mineral fraction; any terrigenous carbonate contained in the dust falling through the water column or deposited in marine sediments is therefore 
eliminated as well. So, in order to make both data sets comparable, carbonates must be removed from our deposited dust at Mbour. Also, when carbonates are present, major element contents ( $\mathrm{Ca}$ in particular) primarily reflect the relative proportion of carbonates and silicates, blurring to some extent the potentially valuable geochemical information contained in the dust silicate fraction considering the diverse geology of West Africa. Besides, carbonate content (and other soluble fractions) cannot be considered as conservative tracers as they can partly dissolve and/or undergo chemical reactions in the atmosphere or after deposition (acidic substances such as $\mathrm{SO}_{2}$ or $\mathrm{H}_{2} \mathrm{SO}_{4}$ for instance may convert carbonates to sulfates; Glaccum and Prospero, 1980). Discrete measurements of Ca in the sodium acetate leachate for a selection of samples provided an indicative range of $<1$ to $6 \%$ for minimal calcium carbonate content in our deposited dust samples, in line with earlier measurements made on dust collected in Mali and in the Cape Verde islands (these measurements do not account for any dissolution that may occur in the ultra-pure water that contains the dust initially though); higher contents have been reported in regions further to the north and northern of Northern Africa though, in Morroco and Algeria in particular (Scheuvens et al., 2013). After carbonate removal followed by three thorough rinsing with ultra-pure water, dust was dried, weighed, and then digested using a $\mathrm{HF}-\mathrm{HNO}_{3} 2: 1$ mixture prior to ICP-OES analyses at the LAboratoire de Spectroscopie pour les Interactions, la Réactivite et I'Environnement (LASIRE) of the University of Lille. A total of 10 elements were determined simultaneously (Al, Fe, K, Mg, Ti, Na, Ca, P, Mn, and Y). Two geological standards (HISS-1 and MESS-3) were prepared following the same protocol and run regularly to ensure analytical correctness; obtained contents were within $5 \%$ of the certified values except for $\mathrm{P}$ and $\mathrm{Ti}$ for which it was with in $10 \%$. Experimental blanks were prepared for each sample batch and yields were always below detection limits. Si content was determined as the difference between the total mass of the sample and the mass of other major oxides measured $\left(\mathrm{SiO}_{2}=100 \%-\left\{\mathrm{Al}_{2} \mathrm{O}_{3}+\mathrm{Fe}_{2} \mathrm{O}_{3}+\mathrm{K}_{2} \mathrm{O}+\mathrm{MgO}+\mathrm{TiO}_{2}+\mathrm{Na}_{2} \mathrm{O} \mathrm{CaO}+\mathrm{P}_{2} \mathrm{O}_{5}+\mathrm{MnO}\right\}\right)$.

Particulate Matter smaller than $10 \mu \mathrm{m}$ (PM10) concentrations were measured at 10m high using a Tapered Element Oscillating Microbalance (TEOM 1400A from Thermo Scientific) equipped with a PM10 inlet (see Marticorena et al., 2010, for details). Backtrajectories reaching Mbour were calculated every 6 hours with HYSPLIT dispersion model (Stein et al., 2015) and $1^{\circ} \times 1^{\circ}$ GDAS meteorological input data; ending altitude was set to $250 \mathrm{~m}$ above ground in order to document low level dust atmospheric transport within the trade winds (Chiapello et al., 1995; 1997). Calculations and analyses have been performed with ZeFir (Petit et al., 2017).

Figure 1

\section{Results and discussion}

\subsection{Contrasting dry and wet seasons for dust deposition}

Total (dry plus wet) mineral dust deposition flux $\left(<30 \mu \mathrm{m}\right.$ carbonate-free fraction; $\mathrm{mg} / \mathrm{m}^{2} / \mathrm{d}$ ) is presented in Figure 1. The two-year time series confirms the seasonal character of dust deposition on the West African margin, as first revealed by Skonieczny et al. (2013) based on a three-year record (2006-2009) obtained at this site. Dust flux baseline is overall higher during the dry season (no rain fall is generally recorded at Mbour from October to June, although year to year variability occurs; Figure 1). Dust deposition is particularly sustained from December through April, when mass flux generally exceeds $100 \mathrm{mg} \cdot \mathrm{m}^{-2} \cdot \mathrm{d}^{-1}$. At this time of the year, North-eastern to Eastern continental trade winds blow over West Africa, regularly carrying vast amount of dust towards the tropical Atlantic Ocean (Chiapello et al., 1995 ; Schepanski et al., 2009) at low atmospheric levels (i.e., within the first $3 \mathrm{~km}$ ), as acknowledged by LIDAR measurements (Veselovskii et al., 2016). The seasonal variability in dust deposition observed on the Senegalese margin is similar to that of the dust concentration observed in French Guyana (Prospero et al., 1981), illustrating the fact that West African and North- eastern SouthAmerican margins lay at the two ends of the "southern" winter plume (as defined in Prospero et al., 
2014), which is driven by the winter monsoon trade wind circulation over West Africa and the tropical Atlantic (often referred to as the Harmattan winds when blowing over West Africa). Highest dust fall at Mbour was recorded at the end of February and at the beginning of March (both in 2014 and 2015), in agreement with earlier observations at this site (Skonieczny et al., 2011; 2013).

Lower fluxes are seen overall during the wet summer season through the early fall (from July to October; Figure 1), when background dust deposition can fall down to $5 \mathrm{mg} \cdot \mathrm{m}^{-2} \cdot \mathrm{d}^{-1}$. Major dust transport towards the Atlantic still occurs over the West African margin during the summer season, as shown by optical measurements at Mbour (Leon et al., 2009). This westward dust transport, however, occurs at higher altitude (up to $6 \mathrm{~km}$ ) in the so-called Saharan Air Layer (hereinafter SAL), above the trade winds that blow North-South along the West African margin and that have often a marine origin at this time of the year (Figure 2.b; Chiapello et al., 1995); by contrast, higher altitude winds traverse the Saharan region (see supplementary material S1) -where strong convective systems due to the intense solar radiation may inject dust at high altitudes- before crossing the Atlantic. As a result, the "summer dust plume" (Prospero et al., 2014), often reaching the Caribbean (Prospero et al., 1999), goes somewhat unnoticed on the ground (low suspended and deposited dust) along the West African margin and the nearby Eastern Tropical Atlantic Ocean (Chiapello et al., 1995), as illustrated by the time series presented here. Yet, a few significant dust deposition events occur from June to early August (see next section). Low dust deposition at the sampling site in the early fall likely reflects primarily the relative weakness of dust activity across the Sahara/Sahel region throughout this period (Prospero et al., 2002).

Figure 2

\subsection{Dust deposition spikes associated with major Saharan outbreaks}

As identified previously at Mbour (Skonieczny et al., 2011; 2013), the 2013-2015 times series confirms the occurrence of several major deposition events each year. The latter are characterized by a sharp increase in dust flux compared to the seasonal background (Figures 1 and 3), which can be multiplied by a factor up to 10 or even more over a $24 \mathrm{~h}$ period despite already high background levels in most cases. In fact, major deposition events nearly all occur during the dry season, from December to April; two sizeable events occurred in July 2013 and May 2014 though, at the transition between dry and wet seasons. Also, a massive deposition event was recorded during the summer 2014; this event, which yielded the largest dust deposit (recorded over a week) of the entire time series, accounted alone for $14 \%$ of the yearly deposition. Consequently, July-to-October dust falls contribution reached $39 \%$ in 2014-15 (it was 23\% in 2013-14).

The highest daily fluxes, however, were recorded around the month of March (early in the month, both in 2014 and 2015, and early April in 2013), consistent with earlier observations (Skonieczny et al., 2013). While dust flux rarely drops below $50 \mathrm{mg} \cdot \mathrm{m}^{-2} \cdot \mathrm{d}^{-1}$ during the dry season, major events may yield fluxes up to $2000 \mathrm{mg} \cdot \mathrm{m}^{-2} \cdot \mathrm{d}^{-1}$ (Figure 1). Major peaks shown here are somewhat higher than the ones that were recorded over the 2006-2009 period (Skonieczny et al., 2013). This is likely due in part to the higher temporal resolution (generally one day) across most dry-season dust flux peaks recorded during the 2013-2015 period compared to the earlier record; the increased sampling resolution allows to capture more faithfully the extent of the dust deposition flux temporal changes. In fact, our record reveals that most major deposition events often do not last more than a few days, as also acknowledged by PM10 dust concentration at our site (Figure 1; Marticorena et al., 2017), highlighting the transient character of the Saharan outbreaks that these deposition events are associated with, as shown by satellite images (Gonzalez and Briottet, 2017) and model outputs (Westphal et al., 2009). Satellite images and dust transport model calculations attest that all major deposition events recorded at Mbour during the study period were associated with large Saharan dust outbreaks travelling across West Africa towards the Atlantic. An example of such event is provided in supplementary material S2. 
As noted by Skonieczny et al. (2013), major deposition events (i.e., when dust flux increased significantly; an arbitrary threshold was set here at 2.5 times the 9-sample running mean) during dry and wet seasons altogether make up a significant part of the yearly flux at Mbour (45 \% in 2013-2014, $35 \%$ in 2014-2015, while their total duration is only 13\% of the year both in 2013-2014 and in 20142015). The estimated yearly flux (33,4 g.m $\mathrm{m}^{-2} \cdot \mathrm{y}^{-1}$ from March 2013 to February 2014 and 43,5 g.m $\mathrm{m}^{-2} \cdot \mathrm{y}^{-1}$ from March 2014 to February 2015) was similar to the ones obtained during the 2006-2009 period. These values compare well with dust accumulation rates found in the water column of the nearby Atlantic Ocean (typically around $35 \mathrm{~g} \cdot \mathrm{m}^{-2} \cdot \mathrm{y}^{-1}$; Fischer et al., 2016).

\subsection{Seasonal changes in the elemental composition of the deposited dust}

Measured elemental concentrations and elemental ratios are close to crustal values (Taylor and McLennan, 1985). Data obtained at Mbour are generally within the range found in the literature for aerosols in West Africa (Formenti et al., 2008, 2011; Scheuvens et al., 2013). Since carbonates were removed from our deposits, Ca content is, as expected, much lower than data reported for bulk dust samples though. Yet, major element measurements reveal important variability in the chemical composition of the silicate fraction of the dust deposited on the Senegalese coast (Figure 3). All major cations display seasonal shifts, which occur around the transition between dry and wet seasons at Mbour. Lower $\mathrm{K}$ and $\mathrm{Mg}$ contents for instance are recorded during the winter/spring; this trend is observed both in elemental concentration (see supplementary material S3) and in elemental ratios to $\mathrm{Al}$, despite simultaneous decrease in $\mathrm{Al}$ content (Figure 3). Conversely, $\mathrm{Ca}$, Fe and Ti contents or $\mathrm{Ca} / \mathrm{Al}$, $\mathrm{Fe} / \mathrm{Al}$ and Ti/Al increase somewhat during the dry winter/spring season (Figure 3). $\mathrm{Na} / \mathrm{Al}$ displays similar trend to $\mathrm{K} / \mathrm{Al}$ and $\mathrm{Mg} / \mathrm{Al}$ (lowering during the winter/spring), while $\mathrm{P} / \mathrm{Al}$, as well as, to a lesser extent, $\mathrm{Mn} / \mathrm{Al}$ (not shown), display shifts in the same direction as $\mathrm{Ca} / \mathrm{Al}$ and $\mathrm{Ti} / \mathrm{Al}$ (increasing during the dry season; supplementary materials S4).

Figure 3

These major swings in the dust composition in and out of the "wet" season are concomitant to the seasonal change in transport regimes (Figure 2). During the dry winter/spring, back-trajectories indicate that air masses reaching Mbour sweep many different inland sectors encompassing most of West Africa overall and therefore potentially carrying dust from the Sahara and Sahel regions. In contrast, during the summer season, low altitude air masses ending Mbour at 250m have either a marine origin or blow along the West African coast. It is unclear, however, how much of the deposited dust at Mbour during the summer derives from portions of the coastal fringe and from Saharan regions after transport in the SAL and subsequent fallout by gravitational settling or washout by precipitation systems (Skonieczny et al., 2013). The occurrence of wet deposition from elevated dust layers is supported by the fact that some major deposition events (for example at the end of July 2013 and at the end of June 2014; Figure 1) are not matched with suspended dust $\left(\mathrm{PM}_{10}\right)$ concentration increase on the ground unlike during the dry season, when both deposition fluxes and $\mathrm{PM}_{10}$ concentration largely co-vary (this study and Marticorena et al., 2017). The significance of wet deposition processes is also backed by the fact that rain was recorded during all-but-one summer periods for which dust flux increased markedly (precipitation data was only available for a limited period though; supplementary materials S5). Furthermore, the more scattered but overall higher Al content during the summer season (Figure 3), which is closely anti-correlated with $\mathrm{SiO}_{2}$ (quartz particles) content, would be consistent with a relative increase in the deposition of finer Al-rich aluminosilicates particles scavenged from the atmospheric column -possibly within the SAL- by precipitations when the latter occur; this is corroborated by several high-flux periods during which rain was recorded (supplementary materials S5). At any rate, at this time of the year, southern Sahelian regions are likely muted to a large extent due to precipitation and vegetation growth (Philippon et al., 2007) and cannot therefore contribute as much to dust transport. The observed increased in potassium for instance, which is quite efficiently removed by hydrolysis processes, is coherent with less weathered, more northern sources for the dust deposited at our site 
during the summer. The fact that the southern, Sahelian dust region, is contributing less during the summer relative to the more northern Saharan region is also consistent with seasonal clay-mineralogy shifts reported at this site by Skonieczny et al. (2013).

In addition to the step-like swings in most elemental ratios across the dry and wet season changes, it is apparent that dust composition shows higher variability during the dry season (Figure 3). Major and rapid changes occur throughout the winter-spring months, leading to a wider range in the elemental ratios than in the summer (Figure 4). The obtained spans sometimes exceed those previously reported for the entire West African source region (Scheuvens et al., 2013; Figure 4); there is, however, a limited number of data in the literature for the silicate (carbonate-free) fraction of the dust, restricting the comparison to non-soluble elements (in weak acidic solution used to remove carbonates) such as $\mathrm{Fe}, \mathrm{K}$ and possibly P. In any case, the recorded temporal variability in the dust chemical composition highlights the interest of long time series to seize the Saharan dust compositional diversity.

\subsection{Winter-spring major Saharan outbreaks: chemical characteristics and provenance}

Interestingly, major deposition events often stick out in the winter-spring chemical composition time series. During these events, elemental ratios often shift in the opposite direction with respect to the seasonal trend (i.e., away from the winter "background" values, generally towards ratios found during the summer, sometimes exceeding even the highest summer extrema). This is noticeable for several cations: prominent increases in $\mathrm{K} / \mathrm{Al}$, and $\mathrm{Na} / \mathrm{Al}$, for instance, are apparent during most major deposition events (Figure 3 and supplementary materials S4; these trends hold true for elemental concentrations as well); conversely, other ratios such as $\mathrm{Ca} / \mathrm{Al}, \mathrm{Fe} / \mathrm{Al}$ and $\mathrm{P} / \mathrm{Al}$ tend to decrease simultaneously. Subsequently, elemental ratios amongst major deposition events are kept within narrower ranges (Figure 4). This lessening in the dust compositional variability implies that there is a limited compositional diversity between the various sources involved during the largest deposition events. The compositional homogeneity found for the highest fluxes $\left(>400 \mathrm{mg} \cdot \mathrm{m}^{-2} \cdot \mathrm{d}^{-1}\right)$ even suggests that a single prominent dust source region might be at play for these largest deposition events.

Back trajectory analyses offer useful clues to investigate the provenance of the dust reaching our site. As discussed above, during the winter-spring seasons, our site is under the influence of air masses blowing over the entire Northern-to-Eastern sector of the wind rose (Figure 2a). Density probability calculations indicate that, even during the winter-spring seasons, most air masses reaching our site have a northern origin and have travelled across the westernmost regions of West Africa (Figure 5a). When trajectories are weighed up by the dust flux, however, a strikingly contrasting pattern appears: dust deposition is associated markedly with trajectories deriving from the Eastern and North-eastern sectors (Figure 5b). The latter sector encompasses topographic lows in southern Algeria and in northern Mali (Figure 6a) west to Ahaggar and Adrar des Ifoghas mountains already identified by Prospero et al. (2002) as foremost dust sources in West Africa and including the area of the Tanezrouft desert. In this study, Prospero et al. show that topographical depressions, where fine sediment has generally accumulated, hold indeed most of the dust emission "hotspots" worldwide, and in Northern Africa particularly. In the region, these troughs can also represent favorable pathways for low altitude air masses that may be channeled between massifs and enable dust uplift (Evan et al., 2016). One can note that his AlgerianMalian provenance sector identified on the basis of mass fluxes recorded at Mbour corresponds to a large part of "PSA 3" as delineated in their review works by Formenti et al. (2011) and Scheuvens et al. (2013).

Figure 4

The eastern sector, which is also the southernmost sector for dust reaching Mbour, spreads over central Mali and Niger (Figure 6b), mainly, where important dust emissions are known to occur in low lying 
areas found between the Adrar des Ifoghas to the west, the Ahaggar to the north, and the Air massif to the East for instance (Prospero et al., 2002); this Sahelian sector, however, may stretch to Libya and Chad, which holds an area often referred to as the most important dust source worldwide (the Bodele depression surrounded by the Tibesti and Ennedi mountains). Back-trajectories therefore support the assessment that major deposition events are associated with specific transport patterns and that dust conveyed during these outbreaks originates from a limited number of provenance sectors (Figure 6). One can note the western region of our "Sahelian" sector across the Mali-Niger border is also part of "PSA 3" as defined by Formenti et al. (2011) and Scheuvens et al. (2013), but this "Sahelian" sector extends further to the east in Niger, stretching at its easternmost ends towards "PSA 4" in Lybia and "PSA 5" at the Niger-Chad border (Figure 5b).

\section{Figure 5}

Air mass trajectories may be particularly applicable to track the origin of individual dust events when samples are collected over $24 \mathrm{~h}$, a period short enough to avoid major change in transport patterns. In fact, significant modifications in the provenance of air masses reaching our site frequently occur within a few days, making it tricky to determine the potential sector of provenance unambiguously when dust is collected at a weekly resolution. Over the two-year period investigated here, 46 samples were collected with a $\sim 24 \mathrm{~h}$ resolution, all during the dry winter-spring seasons and most of them throughout major dust outbreaks (occasionally, daily samples, were also collected outside those large deposition events); important outbreaks present the triple interest to (1) provide, within a day, sufficient deposited dust for geochemical analyses, (2) overwhelm potential regional/local contributions, and (3) be potentially detectable using remote sensing imaging and dust transport model outputs. Amongst the dust deposits sampled at the highest temporal resolution ( $24 \mathrm{~h})$, many, unsurprisingly, are associated with air masses deriving from the two main sectors of provenance areas delivering dust during major outbreaks (Algerian-Malian and Sahelian; Figure 6a,b and Figure 5b). Others, however, must originate from more western areas of West-Africa (as already pointed out, most air masses reaching our site derive from this sector). Within this western area, back-trajectories enable us to distinguish two families of pathways: one passing close to the West African margin (hereinafter the "coastal sector"; Figure 6c), and another group crossing areas further inland within Western Sahara and Mauritania (hereinafter the "Mauritanian sector"; Figure 6d). Although these regions do not hold dust sources nearly as important as in the Algerian-Malian and Sahelian sectors, significant dust emissions have been reported, particularly in the area to the west and the east of the Adrar Souttouf Mountains for instance in southern Western Sahara (Prospero et al., 2002); these sources are enclosed in "PSA 2" in Scheuvens et al. (2013).

Of all the samples for which a sector of provenance could be determined (i.e., when dust was sampled at a $24 \mathrm{~h}$ resolution), it is apparent that those collected during the largest deposition events (when dust flux exceeds $800 \mathrm{mg} \cdot \mathrm{m}^{-2} \cdot \mathrm{d}^{-1}$ ) are associated with air masses coming from the Algerian-Malian sector (Figure 7 and supplementary material S6). One must note that these samples were collected during two dust deposition events only, each lasting a few days, in February-March 2014 and at the end of February 2015. Back trajectory analysis therefore supports the idea that, during these largest deposition events, the relative uniformity of Saharan dust chemical composition is due to the fact that a single dominant provenance sector was at play in those two cases: the Algerian-Malian sector defined above. The Tanezrouft desert area, in particular, was clearly active during these two events (see supplementary material S2). This desert was already identified as a chief provenance region for dust reaching Mbour during a major Saharan event recorded in 2006 (Skonieczny et al., 2011). At this time of the year, major dust events initiated in this area often engulf a topographic trough between the Atlas and the Ahagaar mountains, which appears as a large dust "highway" across West Africa on satellite images (Middleton et Goudie, 2001; Knippertz and Todd, 2012; Evan et al., 2016; L. Gonzales, personal communication). Based on various satellite observations combined with trajectory simulations, a recent study by Yu et al. (2020) identified this area, referred to as El Djouf, as the primary source for Saharan dust transported across the Atlantic Ocean and the Amazon Basin. Incidentally, the relative narrowness of the chemical 
composition of the mineral dust deposited during major deposition events implies that the chemical signature of the Algerian-Malian sector can be fairly well defined for several major elemental ratios ( $\mathrm{Ca} / \mathrm{Al}, \mathrm{Fe} / \mathrm{Al}, \mathrm{Mg} / \mathrm{Al}, \mathrm{P} / \mathrm{Al}$; Figure 7 and supplementary material S6).

Figure 6

\subsection{Hints regarding the chemical signatures of the various dust provenance sectors in West Africa}

Albeit of lesser importance, large deposition events are also associated with air masses originating from all the other sectors identified above. Amongst the significant deposits sampled with a $24 \mathrm{~h}$ resolution and deriving from these other sectors (as indicated by back-trajectories), some share somewhat similar chemical signatures as those linked to the Algerian-Malian sector (Figure 7). Yet, the various sectors of provenance can be distinguished to a certain extent. Several elemental ratios allow indeed discriminating the Sahelian and Algerian-Malian sectors from one another. It is noticeable for example that the latter is characterized by higher K/Al and Ti/Al compared to the Sahelian sector (Figure 7), as well as by higher $\mathrm{Si} /[\mathrm{Si}+\mathrm{Al}+\mathrm{Fe}]$ ratios as shown in the Si-Fe-Al ternary plot (Figure 8). High Si ratio is coherent with the fact that the Algerian-Malian sector encompasses the Taoudeni Basin where mainly detrital sedimentary series of Proterozoic to Mesozoic ages with abundant sandstones are found (Leprêtre, 2015) and, north of this basin, the Tanezrouft desert, which is covered by dune sands and material derived from Quaternary alluvial deposits (Besler, 1982); Chorowitz and Fabre (1997) report that braided streams and wadis were actually active on the western flanks of the Ahagar during the Holocene.

Conversely, the Sahelian sector displays somewhat higher Fe/Al (Figure 7). As already discussed, this is consistent with the view that chemical weathering is expected to have been more extensive in the Sahel region compared to the Algerian-Malian sector, which lies at the core of the Saharan desert (Moreno et al., 2006). In fact, ancient laterite and especially ferricrete outcrops are common in the Sahelian region (Zeegers and Leprun, 1979). It is likely, however, that chemical differences between the Sahelian and Algerian-Malian sectors, which are best evidenced using ternary diagrams (Figure 8), do not result only from distinct weathering regimes, as suggested by the opposite trend of $\mathrm{K} /[\mathrm{K}+\mathrm{Ca}+\mathrm{Mg}]$ and $\mathrm{Ca} /[\mathrm{K}+\mathrm{Ca}+\mathrm{Mg}]$, for instance (Figure 8 ). Some of the observed signatures likely reflect also the complex and diverse West African geological background, which includes several Precambrian cratonic units, uplifted in places by Cenozoic volcanism (Hoggar and Tibesti mountains in particular; Ayadi et al., 2000; Liégeois et al., 2005). The way each of these geological outcrops have fed present day dust emissions areas with erosional products and affect the dust chemical budget remains to be investigated. Incidentally, the distinct chemical signature of the Sahelian sector compared to the Algerian-Malian highlight the fact that "PSA 3" defined by Scheuvens et al. (2013) likely encompasses emission spots with various geochemical signatures.

The coastal and Mauritanian sectors show a somewhat wider range of signatures that largely superimpose: it is difficult to distinguish them from each other based on major element composition (Figure 7). For most elemental ratios, it is interesting that these two sectors actually display values that spread across part of the Algerian-Malian and Sahelian ranges. This geochemical signatures diversity may reflect the fact that the two western sectors cross a wide latitudinal band and therefore includes regions with contrasting weathering regimes. Also, assuming that a large part of the Saharan dust is deposited over West Africa before it reaches the Atlantic Ocean, the partial overlapping of the chemical composition of dust deriving from the coastal and Mauritanian sectors could reflect in part the fact that northern wind systems reaching our sampling site may regularly carry re-suspended dust initially emitted from various sectors further to the East. Yet, some geochemical signatures carried by the two western sectors (coastal and Mauritanian) are distinct from the other sectors, indicating regional geochemical specificity. In particular, some dust samples deriving from these western sectors present somewhat higher $\mathrm{Ca} / \mathrm{Al}, \mathrm{Mg} / \mathrm{Al}, \mathrm{Fe} / \mathrm{Al}$ than the other sectors (Figure 7). This could be related to 
weathering products derived from mafic rocks such as those outcropping in the Adrar Souttouf Mountains (Villeneuve et al., 2006). High-flux samples associated with air-masses deriving from the coastal sector also display higher P/Al ratios (Figure 7), possibly reflecting the contributions from sources within the Senegalese-Mauritanian coastal basin, where relatively younger formations are found, including marine deposits such as carbonates, evaporites and phosphatic rocks. In its central part, the coastal basin is also characterized by a late Tertiary Fe-rich lateritic crust (Barusseau et al., 2009), whereas late Quaternary aeolian deposits dominate in the NW of the basin. The NAAPS (Navy Aerosol Analysis and Prediction System) dust model occasionally indicates indeed some dust activity on the Mauritanian and even Senegalese coast (Westphal et al., 2009). Overall, the relative diversity of the chemical composition within dust deriving from these western sectors suggests that multiple sources with differing geochemical characteristics are at play. Dust sampling further north along the West African margin would be required to investigate these western sources in greater detail.

Figure 7

\subsection{Background chemical signature and its limited impact on the chemical signature of major dust outbreaks}

The background dust samples collected outside major dust events present a large chemical diversity (Figure 7). Apart from Ti/Al ratios, elemental contents (or ratios) found in these low-flux samples generally span most of the range recorded during major deposition events and associated to the four sectors described above. For most elements, low-flux samples actually extend the span: it is therefore possible to individualize a group of low-flux samples that display strictly distinct chemical signatures from dust collected during major deposition events. It is interesting that air masses associated with these "distinct" samples all have a northern origin, and may thus potentially derive from the western sectors. Assuming that part of the dust collected outside major outbreaks originates from regions closer to Mbour, one may thus hypothesise that these samples reveal the signatures of minor but more proximal sources. The geology of the region of Dakar and Mbour, belonging to the south of the Senegalese-Mauritanian basin, is characterized by a relatively wide lithological variety with mostly Cretaceous to Quaternary sedimentary rocks. Thus, the background dust samples enriched in $\mathrm{P}, \mathrm{Ca}, \mathrm{Fe}$ and $Y$ (supplementary materials S6) could be, for example, related to variable contributions from Eocene phosphate levels with glauconite enrichment (Thiès formation) exposed in the Cap Vert area (Barusseau et al., 2009). Eocene phosphate-rich sedimentary units are also found further north (about $70 \mathrm{~km}$ ) in the Tobène area where phosphate is mined (Prian, 2014).

The fact that none of the dust deposited during the summer carries any of these "distinct" background signatures (Figure 4 and supplementary materials S7) is also consistent with the hypothesis that the latter represent regional, Senegalese signatures; in effect, most of Senegal is covered with vegetation during the wet summer and dust activity is clearly inhibited then. Nevertheless, this sample group does not constitute a homogenous end-member (supplementary materials S7). This suggests that, if regional sources are at play, they are likely multiple. If this is the case, one can hypothesize that the wide range of chemical signatures found during low-flux periods may thus reflect to some extent mixings between long-range transported dusts and variable contributions from "regional" sources as well. One cannot rule out either that particulate matter generated by human activities (road site dust in particular) in and around the city of Mbour may contribute to some extent to the background dust deposited at our site. Considering now the noticeable flux increase during the major deposition events, however, our record suggests that any regional contribution, whether of natural and/or of anthropogenic origin, must be heavily diluted during large Saharan outbreaks, especially those deriving from the Algerian-Malian and Sahelian sectors, when vast amounts of dust are brought across the West-African coast from the main emission hot-spots and that dust flux often increases by an order of magnitude or more. The correlation between the mass flux and provenance from these two principal sectors (Figure $5 b$ ) supports the idea 
that putative regional contributions are essentially overcome by long-range transported dust from main sources during large dust storm events.

\subsection{Intra-sector chemical variability and potential use of Ti content as a transport proxy}

Chemical variability is also observed during major deposition events, albeit to a lesser extent, even when dust derives from the two main sectors of provenance (Algerian-Malian and Sahelian). Dust associated with the air masses deriving from the Sahelian sector, in particular, display variable signatures. Amongst them, a couple, for instance, show potassium values that are significantly higher than the others. Backtrajectories reveal that winds associated with these samples have followed a more northern path within the Sahel, between Niger and Algeria, compared to samples displaying lower K/Al (for which corresponding back-trajectories pass over southern Niger and Chad; see supplementary materials S8 and S9); this is consistent with the hypothesis that potassium content in soils/sediments decreases with latitude in the region as chemical weathering intensifies. The fact that subtle alteration in the chemical composition may be associated to difference in air mass provenance far away from our sampling site strengthen the view that contribution from potential regional emissions is minor, at least during Saharan outbreaks.

Figure 8

In addition to differences in the chemical signatures of the various sources involved in each sector, one can hypothesize that some of the variability results from variable grain size sorting during transport, leading to chemical fractionation with preferential loss of heavier minerals during transport. This is most obvious for titanium, which displays contrasting ratios to aluminium during major events, even when they derive from the same sector of provenance; for example, opposite to other elements, most variable $\mathrm{Ti} / \mathrm{Al}$ is recorded during the two largest deposition events during the dry season (Figure 7). Since Ti is carried by refractory heavy mineral such as rutile, ilmenite, anatase or titanite [e.g., Scheuvens et al., 2013], it is generally associated with coarser particles and has therefore often been used as a proxy for aeolian dust (in contrast to river borne particles) in marine sediments [Kola et al., 1979; Wehausen and Brumsack, 1999; Govin et al., 2012] and for wind strength in particular [Boyle, 1983; Grousset et al., 1998]. Changing Ti content in our record may thus primarily reflect variable wind vigour during uplift and transport and/or variable distance of transport, which both may induce variable grain size sorting. The effect of transport distance is supported by back trajectory analysis: higher Ti/Al is observed when the potential transport distance is shorter (see supplementary materials S10). Similarly, lower Ti/Al ratios for the Sahelian sector (Figure 7) could be related to longer dust transport than for dust deriving from the Algerian-Malian area. Incidentally, these results support the use of Ti content variability as a proxy for grain size changes in sedimentary record (e.g., Revel et al., 2014).

The fact that $\mathrm{Ti}$ might be indicative of grain size is also supported by summer dust deposits. It is remarkable that lower Ti/Al ratios are indeed recorded during the wet season, compared to dust deposited during the winter-spring dry season. Besides, within the summer period itself, Ti/Al ratio is generally higher when no rain is recorded than when rain occurs during the sampling interval (supplementary material S5). Lowering of Ti/Al ratio is particularly marked during major deposition events (Figures 3 and 4; supplementary material S5). Such a striking difference in Ti/Al suggests that during these major summer events, dust deposits contain finer grains. Skonieczny et al. (2013) actually reported a significant drop in grain size during the largest wet deposition event of the 2006-2009 time series. As discussed earlier, this is coherent with wet removal processes that may scavenge the whole atmospheric dust load including fine particles, while dry deposition processes favor coarse grains fallout as finer clay size particles may stay in suspension much longer (Skonieczny et al., 2013). Considering the significance of these events in terms of deposited mass, the fact that they may be of finer size supports the hypothesis of washout from the SAL. Summer Ti contents are actually close to values obtained for dust in rainfall collected in Niger (Desboeufs et al., 2010) as well as dust transported to the Barbados 
within the SAL during summer 2013 and 2014 (Bozlaker et al., 2018). The prevalence of wet deposition in summer was already noted at this site by Marticorena et al. (2017), and is consistent with studies across the Tropical Atlantic based on sediment trap data (Bory et al., 2002b; van der Does et al., 2020) and various remote sensing products and trajectory statistics (Yu et al., 2020).

The overall chemical composition of these occasional summer events is somewhat distinct from that of the winter/spring events, suggesting a contribution from different sources or a mix of sources during the summer at our site. The lower (weekly) sampling resolution during the summer, the unknown and possibly variable altitude of the dust transport, the uncertainties regarding dust deposition process at our site (together with incomplete precipitation records), and the possible occurrence of rainfall events upstream of our sampling site, all combine to render trajectory analysis largely inapplicable unfortunately. Also, satellite images and model outputs indicate important dust activity along a very broad area at these times, making it difficult to assess the possible origin of the dust based on these tools as well. Furthermore, meteorological conditions at this time of the year may favor intense mixing of dust from various provenance. This was recently highlighted in a case study of a massive dust event that impacted both sides of the Tropical Atlantic Ocean, and during which dust emitted from multiple sources accumulated for several days towards the African coast before being carried across the Atlantic Ocean (Yu et al., 2021). Besides, atmospheric mixing processes could explain the somewhat more homogenous geochemical dust signature observed in the summer (which cannot be explained by the lowering of sampling resolution only). Finally, as discussed above, one cannot exclude also that part of the observed compositional differences between summer and winter/spring major dust deposition events result in some measure from differing grain size distribution. Grain size distribution measurements as well as elemental analyses within different class size would be most useful to advance this hypothesis, especially as previous investigations have reported mixed information with both finer and coarser deposits during the summer season (Skonieczny et al., 2013). Generally, considering the weight of summer major events contribution on the annual deposition flux (see section 3.2), a more comprehensive assessment of the potential influence of transport processes on the dust major elements signature would be required in order to improve our ability to interpret the changes in the geochemical composition of Saharan dust archived in marine sediments. This is particularly important considering that sediment records can be obtained at various latitudes and at variable distances from potential sources areas, in locations were the influence of the summer vs winter/spring transports likely differs (van der Does et al., 2020). In any case, our investigations underlines the complexity of Saharan dust transport towards the Atlantic, due to the various contributing sources and the seasonal changes in transport patterns, calling for caution when discussing the significance of Atlantic sediment dust records.

\section{Main outcomes and conclusions}

A unique 2-year record of the chemical composition (major elements) of Saharan dust deposits (<30 $\mu \mathrm{m}$ silicate fraction) was obtained at Mbour, Senegal, between March 2013 and February 2015, along side with mass flux measurements. The chosen sampling location was particularly well suited to monitor dust transport from a wide geographic area within Western Sahara and Sahel. In fact, as validated by the computing of back-trajectories over the study period with the HYSPLIT model, Mbour receives air masses originating from all directions within the North-to-East sector of the wind rose), chiefly during the dry winter/spring season at Mbour when continental trade winds (Harmattan) blow over West Africa at low atmospheric levels towards the Atlantic Ocean. Accordingly, higher dust deposition was recorded at this time of the year (from December to April), in agreement with earlier measurements at this site (Skonieczny et al., 2013); during the wet summer season at Mbour, our record attests that dust deposition flux is generally much lower. 
Major element analyses revealed that the chemical composition of the carbonate-free fraction of Saharan dust was more diverse than expected from previous investigations and underwent important seasonal changes. Shifts in elemental contents were found at around the dry and wet season transitions, implying marked change in provenance and/or transport and deposition processes. Unlike during the winter/spring season, air mass back-trajectories indicated that low altitude air masses are confined along the West African coast during the summer, inferring that only limited amounts of dust may thus be carried to our site by surface winds compared to the winter/spring trades. Our record suggests that additional deposition of dust through wet-removal processes of dust transported at higher atmospheric levels likely plays a role during the rainy summer season.

One of the most striking features of the 2-year mass flux record is the occurrence of major deposition events, which account altogether for up to nearly half of the yearly flux. These large deposition events take place mainly during the dry winter/spring season, but also during the rainy summer season, despite the much higher altitude of transport at this time of the year: the largest weekly deposit was actually recorded in July 2014 and yielded $\sim 15 \%$ of the yearly deposition. Such an important wet deposition event could result from rain washout of finer dust transported at high altitude within the so-called Saharan Air Layer (SAL), as supported by the distinct Al-rich and Ti-poor dust composition during these events (Al and Ti being enriched in fine aluminosilicates and heavy minerals, respectively). However, most major deposition events were recorded during the dry season, when mass flux can occasionally exceed $1000 \mathrm{mg} \cdot \mathrm{m}^{-2} \cdot \mathrm{d}^{-1}$. Satellite images and dust transport models showed that these large deposition events are associated with broad dust outbreaks sweeping across West Africa. Density probability calculations revealed that the higher fluxes recorded at Mbour were generally associated with trajectories deriving from two main sectors of provenance, one including southern Algeria and Northern Mali (the Tanezrouft desert in particular), and another one lying further to the south within the Sahel region encompassing known source regions in Mali, Niger and possibly further to the East in Chad and Lybia. Yet, the Algerian-Malian sector was clearly found to be the dominant source region for the dust delivered to Mbour.

By associating each sample collected at the highest temporal resolution (24h) with corresponding backtrajectories, we then attempted to assess the signature of the main provenance sectors providing dust to our sampling site. Although dust deposited during major events displayed a narrower diversity within the entire two-year range, we found that it was still possible to chemically distinguish the two main provenance sectors. Despite some partial overlap, the Algerian-Malian area displays higher K/Al and Ti/Al ratios for instance compared to the Sahelian sector characterized by higher Fe/Al. While the observed differences may be related to variable degrees of weathering and geological backgrounds, further geochemical and mineralogical investigations are required to better constrain this point. Considering the important weight of the Algerian-Malian sector in the dust delivered to Mbour, its chemical signature, which appeared to be quite well constrained, likely represents the dominant signature of the Saharan dust deposited over the North-eastern tropical Atlantic, at least within the latitudinal band of Senegal. Two other sectors, encompassing coastal and more inland areas in Mauritania and Western Sahara, as well as possible regional Senegalese sources, were also identified; their chemical signatures, however, were somewhat scattered and thus more difficult to define and discriminate between them and from the other sectors. Anyhow, considering the limited amount of large dust events recorded over the study period though, longer monitoring of dust deposition and additional case studies will be required to confirm and refine the characterization of the different provenance sectors, even the major ones.

Yet, the 2-year record of dust deposition obtained at Mbour provided overall a unique insight in the chemical composition of the Saharan dust (silicate fraction) delivered to the West African coast, and by extension to the Tropical North-Eastern Atlantic Ocean. The tentative partial differentiation of several sectors of provenance based on major elements highlights the interest of investigating the carbonatefree fraction of the dust and calls for complementary investigations based on trace elements and/or 
radiogenic isotopes for instance. The latter should help furthering the geochemical discrimination of the various source regions within the Saharan-Sahel desert (Skonieczny et al., 2013). Source fingerprinting is indeed key to our interpretation of the changes in the magnitude and in the composition of dust deposits in the nearby North-eastern Tropical Atlantic Ocean sediments, in terms of geographical shifts in aridity over the Saharan region for instance (e.g., Colin et al., 2014). Characterizing the mineralogical and chemical signatures of the main Saharan dust sources is also useful to incorporate these properties in dust transport models (Li et al., 2021). Finally, our record underlines the interest of building long time series in order to seize the full range of the dust compositional variability, assess seasonal variations, and weigh the significance of sporadic but major outbreaks and wet deposition events in the deposition budget.

\section{Acknowledgements}

PM10 measurements in Mbour were performed in the framework of the French National Observatory Service INDAAF (International Network to study Deposition and Atmospheric composition in AFrica; https://indaaf.obs-mip.fr/) that is supported since 2010 by the INSU/CNRS, the IRD and the Observatoire des Sciences de I'Univers EFLUVE. The authors gratefully acknowledge the NOAA Air Resources Laboratory (ARL) for the provision of the HYSPLIT transport and dispersion model (http://www.ready.noaa.gov) used in this publication, and the US Naval Research Laboratory for access to the NAAPS (Navy Aerosol Analysis and Prediction System) dust transport model outputs (https://www.nrlmry.navy.mil/aerosol/). This work was supported by the French national program LEFE/INSU and the CaPPA project (Chemical and Physical Properties of the Atmosphere) funded by ANR (ANR-II-LABX-0005-01). We are grateful to three anonymous reviewers for their thorough and helpful comments, and we thank Y. Le Quilleuc for his assistance while editing the figures. Data will be accessible on PANGAEA (www.pangaea.de) by acceptance.

\section{References}

Arimoto, R., 2001. Eolian dust and climate: Relationships to sources, tropospheric chemistry, transport and deposition, Earth-Science Reviews 54 (1-3), 29-42. [doi: 10.1016/S0012-8252(01)00040-X]

Ayadi, A., C. Dorbath, A. Lesquer, M. Bezzeghoud, 2000. Crustal and upper mantle velocity structure of the Hoggar swell (Central Sahara, Algeria), Physics of the Earth and Planetary Interiors 118 (1-2), 111123. [doi: 10.1016/S0031-9201(99)00134-X]

Barusseau, J. P., C. Duvail, B. J. Noël, P. Nehlig, J. Roger, O. Serrano (2009). Notice explicative de la carte géologique du Sénégal à 1/500 000, feuilles nord-ouest, nord-est et sud-ouest. d. I. I. e. d. P. Ministère des Mines, Direction des Mines et de la Géologie, Dakar, Sénégal, 61p.

Besler, H., 1982. A contribution to the aeolian history of the Tanezrouft, Bulletin de l'Association de géographes français 59 (483), 55-60. [doi: 10.3406/bagf.1982.5306]

Bory, A. J.-M., P. E. Biscaye, A. Svensson, F. E. Grousset, 2002a. Seasonal variability in the origin of recent atmospheric mineral dust at NorthGRIP, Greenland, Earth and Planetary Science Letters 196 (3-4), 123134. [doi: 10.1016/S0012-821X(01)00609-4]

Bory, A., F. Dulac, C. Moulin, I. Chiapello, P. P. Newton, W. Guelle, C. E. Lambert, G. Bergametti, 2002b. Atmospheric and oceanic dust fluxes in the northeastern tropical Atlantic Ocean: how close a coupling?, Annales Geophysicae 20 (12), 2067-2076, doi:2010.5194/angeo-2020-2067-2002. [doi: 
Bozlaker, A., J. M. Prospero, J. Price, S. Chellam, 2018. Linking Barbados Mineral Dust Aerosols to North African Sources Using Elemental Composition and Radiogenic $\mathrm{Sr}, \mathrm{Nd}$, and Pb Isotope Signatures, Journal of Geophysical Research: Atmospheres 123 (2), 1384-1400. [doi: 10.1002/2017JD027505]

Bristow, C. S., K. A. Hudson-Edwards, A. Chappell, 2010. Fertilizing the Amazon and equatorial Atlantic with West African dust, Geophysical Research Letters 37 (14), L14807. [doi: 10.1029/2010GL043486]

Caquineau, S., A. Gaudichet, L. Gomes, M. Legrand, 2002. Mineralogy of Saharan dust transported over northwestern tropical Atlantic Ocean in relation to source regions, Journal of Geophysical Research: Atmospheres 107 (D15), 4251. [doi: 10.1029/2000JD000247]

Chiapello, I., G. Bergametti, B. Chatenet, P. Bousquet, F. Dulac, E. S. Soares, 1997. Origins of African dust transported over the northeastern tropical Atlantic, Journal of Geophysical Research: Atmospheres 102 (D12), 13701-13709. [doi: 10.1029/97JD00259]

Chiapello, I., G. Bergametti, L. Gomes, B. Chatenet, F. Dulac, J. Pimenta, E. S. Suares, 1995. An additional low layer transport of Sahelian and Saharan dust over the north-eastern Tropical Atlantic, Geophysical Research Letters 22 (23), 3191-3194. [doi: 10.1029/95GL03313]

Chien, C. T., K. R. M. Mackey, S. Dutkiewicz, N. M. Mahowald, J. M. Prospero, A. Paytan, 2016. Effects of African dust deposition on phytoplankton in the western tropical Atlantic Ocean off Barbados, Global Biogeochemical Cycles 30 (5), 716-734. [doi: 10.1002/2015gb005334]

Chorowicz, J., J. Fabre, 1997. Organization of drainage networks from space imagery in the Tanezrouft plateau (Western Sahara): Implications for recent intracratonic deformations, Geomorphology 21, 139151. [doi: 10.1016/S0169-555X(97)00041-X]

Colin, C., G. Siani, Z. Liu, D. Blamart, C. Skonieczny, Y. Zhao, A. Bory, N. Frank, S. Duchamp-Alphonse, F. Thil, T. Richter, C. Kissel, J. Gargani, 2014. Late Miocene to early Pliocene climate variability off NW Africa (ODP 659), Palaeogeography Palaeoclimatology Palaeoecology 401, 81-95. [doi: 10.1016/j.palaeo.2014.1002.1015]

De Longueville, F., Y.-C. Hountondji, S. Henry, P. Ozer, 2010. What do we know about effects of desert dust on air quality and human health in West Africa compared to other regions?, Science of The Total Environment 409 (1), 1-8. [doi: 10.1016/j.scitotenv.2010.09.025]

DeMott, P. J., K. Sassen, M. R. Poellot, D. Baumgardner, D. C. Rogers, S. D. Brooks, A. J. Prenni, S. M. Kreidenweis, 2003. African dust aerosols as atmospheric ice nuclei, Geophysical Research Letters 30 (14). [doi: 10.1029/2003GL017410]

Derimian, Y., A. Karnieli, Y. J. Kaufman, M. O. Andreae, T. W. Andreae, O. Dubovik, W. Maenhaut, I. Koren, 2008. The role of iron and black carbon in aerosol light absorption, Atmospheric Chemistry and Physics 8 (13), 3623-3637. [doi: 10.5194/acp-8-3623-2008]

Desboeufs, K., E. Journet, J.-L. Rajot, S. Chevaillier, S. Triquet, P. Formenti, A. Zakou, 2010. Chemistry of rain events in West Africa: Evidence of dust and biogenic influence in convective systems, Atmospheric Chemistry and Physics 10 (19), 9283-9293. [doi: 10.5194/acp-10-9283-2010]

Dunion, J. P., C. S. Velden, 2004. The Impact of the Saharan Air Layer on Atlantic Tropical Cyclone Activity, Bulletin of the American Meteorological Society 85 (3), 353-366. [doi: 10.1175/BAMS-85- 3353] 
Evan, A. T., C. Flamant, M. Gaetani, F. Guichard, 2016. The past, present and future of African dust, Nature 531 (7595), 493-495. [doi: 10.1038/nature17149]

Fischer, G., O. Romero, U. Merkel, B. Donner, M. Iversen, N. Nowald, V. Ratmeyer, G. Ruhland, M. Klann, G. Wefer, 2016. Deep ocean mass fluxes in the coastal upwelling off Mauritania from 1988 to 2012: Variability on seasonal to decadal timescales, Biogeosciences 13 (10), 3071-3090. [doi: 10.5194/bg-133071-2016]

Formenti, P., J. L. Rajot, K. Desboeufs, S. Caquineau, S. Chevaillier, S. Nava, A. Gaudichet, E. Journet, S. Triquet, S. Alfaro, M. Chiari, J. Haywood, H. Coe, E. Highwood, 2008. Regional variability of the composition of mineral dust from western Africa: Results from the AMMA SOPO/DABEX and DODO field campaigns, Journal of Geophysical Research: Atmospheres 113, D00C13. [doi: 10.1029/2008JD009903]

Formenti, P., L. Schütz, Y. Balkanski, K. Desboeufs, M. Ebert, K. Kandler, A. Petzold, D. Scheuvens, S. Weinbruch, D. Zhang, 2011. Recent progress in understanding physical and chemical properties of African and Asian mineral dust, Atmospheric Chemistry and Physics 11 (16), 8231-8256. [doi: 10.5194/acp-11-8231-2011]

Fuhrer, K., E. W. Wolff, S. J. Johnsen, 1999. Timescales for dust variability in the Greenland Ice Core Project (GRIP) ice core in the last 100,000 years, Journal of Geophysical Research: Atmospheres 104 (D24), 31043-31052. [doi: 10.1029/1999JD900929]

Glaccum, R., J. Prospero, 1980. Saharan Aerosols over the Tropical North Atlantic - Mineralogy, Marine Geology 37, 295-321. [doi: 10.1016/0025-3227(80)90107-3]

Gonzalez, L., X. Briottet, 2017. North Africa and Saudi Arabia Day/Night Sandstorm Survey (NASCube), Remote Sensing 9 (9), 896. [doi: 10.3390/rs9090896]

Goossens, D., J. L. Rajot, 2008. Techniques to measure the dry aeolian deposition of dust in arid and semi-arid landscapes: A comparative study in West Niger, Earth Surface Processes and Landforms 33 (2), 178-195. [doi: 10.1002/esp.1533]

Grant, K. M., E. J. Rohling, T. Westerhold, M. Zabel, D. Heslop, T. Konijnendijk, L. Lourens, 2017. A 3 million year index for North African humidity/aridity and the implication of potential pan-African Humid periods, Quaternary Science Reviews 171, 100-118. [doi: 10.1016/j.quascirev.2017.07.005]

Grousset, F. E., M. Parra, A. Bory, P. Martinez, P. Bertrand, G. Shimmield, R. M. Ellam, 1998. Saharan wind regimes traced by the $\mathrm{Sr}-\mathrm{Nd}$ isotopic composition of subtropical Atlantic sediments: Last Glacial maximum vs today, Quaternary Science Reviews 17 (4-5), 395-409. [doi: 10.1016/S02773791(1097)00048-00046]

Journet, E., K. V. Desboeufs, S. Caquineau, J.-L. Colin, 2008. Mineralogy as a critical factor of dust iron solubility, Geophysical Research Letters 35 (7), L07805. [doi: 10.1029/2007GL031589]

Knippertz, P., M. C. Todd, 2012. Mineral dust aerosols over the Sahara: Meteorological controls on emission and transport and implications for modeling, Reviews of Geophysics 50. [doi: 10.1029/2011rg000362]

Lafon, S., I. N. Sokolik, J. L. Rajot, S. Caquineau, A. Gaudichet, 2006. Characterization of iron oxides in mineral dust aerosols: Implications for light absorption, Journal of Geophysical Research 111 (D21), D21207. [doi: 10.1029/2005JD007016] 
Lambert, F., A. Tagliabue, G. Shaffer, F. Lamy, G. Winckler, L. Farias, L. Gallardo, R. De Pol-Holz, 2015. Dust fluxes and iron fertilization in Holocene and Last Glacial Maximum climates, Geophysical Research Letters 42 (14), 6014-6023. [doi: 10.1002/2015GL064250]

Larrasoana, J. C., A. P. Roberts, E. J. Rohling, M. Winklhofer, R. Wehausen, 2003. Three million years of monsoon variability over the northern Sahara, Climate Dynamics 21 (7-8), 689-698. [doi: 10.1007/s00382-003-0355-z]

Legrand, M., A. Plana-Fattori, C. N'Doume, 2011. Satellite detection of dust using the IR imagery of Meteosat 1. Infrared difference dust index, Journal of Geophysical Research-Atmospheres 106, 18251 18274. [doi: 10.1029/2000JD900749]

Léon, J.-F., Y. Derimian, I. Chiapello, D. Tanré, T. Podvin, B. Chatenet, A. Diallo, C. Deroo, 2009. Aerosol vertical distribution and optical properties over M'Bour (16.96\&deg; W; 14.39\&deg; N), Senegal from 2006 to 2008, Atmospheric Chemistry and Physics 9 (23), 9249-9261. [doi: 10.5194/acp-9- 9249-2009]

Leprêtre (2015). Evolution phanérozoïque du Craton Ouest Africain et de ses bordures Nord et Ouest. Doctorate Doctoral thesis, Université Paris Sud.

Li, L., O. Dubovik, Y. Derimian, G. L. Schuster, T. Lapyonok, P. Litvinov, F. Ducos, D. Fuertes, C. Chen, Z. Q. Li, A. Lopatin, B. Torres, H. Z. Che, 2019. Retrieval of aerosol components directly from satellite and ground-based measurements, Atmospheric Chemistry and Physics 19 (21), 13409-13443. [doi: 10.5194/acp-19-13409-2019]

Li, L., N. M. Mahowald, R. L. Miller, C. Perez Garcia-Pando, M. Klose, D. S. Hamilton, M. Goncalves Ageitos, P. Ginoux, Y. Balkanski, R. O. Green, O. Kalashnikova, J. F. Kok, V. Obiso, D. Paynter, D. R. Thompson, 2021. Quantifying the range of the dust direct radiative effect due to source mineralogy uncertainty, Atmospheric Chemistry and Physics 21 (5), 3973-4005. [doi: 10.5194/acp- 21-3973-2021]

Liégeois, J. P., A. Benhallou, A. Azzouni-Sekkal, R. Yahiaoui, B. Bonin (2005). "The Hoggar swell and volcanism: Reactivation of the Precambrian Tuareg shield during Alpine convergence and West African Cenozoic volcanism." in Plates, plumes, and paradigms. G. R. Foulger, J. H. Natland, D. C. Presnall and D. L. Anderson: 379-400.

Linnemann, U., K. Ouzegane, A. Drareni, M. Hofmann, S. Becker, A. Gartner, A. Sagawe, 2011. Sands of West Gondwana: An archive of secular magmatism and plate interactions - A case study from the Cambro-Ordovician section of the Tassili Ouan Ahaggar (Algerian Sahara) using U-Pb-LA-ICP-MS detrital zircon ages, Lithos 123 (1-4), 188-203. [doi: 10.1016/j.lithos.2011.01.010]

Linnemann, U., K. Ouzegane, A. Drareni, M. Hofmann, S. Becker, A. Gärtner, A. Sagawe, 2011. Sands of West Gondwana: An archive of secular magmatism and plate interactions-A case study from the Cambro-Ordovician section of the Tassili Ouan Ahaggar (Algerian Sahara) using U-Pb-LA-ICP-MS detrital zircon ages, Lithos 123, 188-203. [doi: 10.1016/j.lithos.2011.01.010]

Marticorena, B., B. Chatenet, J. L. Rajot, G. Bergametti, A. Deroubaix, J. Vincent, A. Kouoi, C. Schmechtig, M. Coulibaly, A. Diallo, I. Koné, A. Maman, T. NDiaye, A. Zakou, 2017. Mineral dust over west and central Sahel: Seasonal patterns of dry and wet deposition fluxes from a pluriannual sampling (2006-2012): Mineral Dust Deposition Over the Sahel, Journal of Geophysical Research: Atmospheres 122 (2), 13381364. [doi: 10.1002/2016JD025995] 
Marticorena, B., B. Chatenet, J. L. Rajot, S. Traore, M. Coulibaly, A. Diallo, I. Kone, A. Maman, T. Ndiaye, A. Zakou, 2010. Temporal variability of mineral dust concentrations over West Africa; analyses of a pluriannual monitoring from the AMMA Sahelian Dust Transect, Atmospheric Chemistry and Physics 10 (18), 8899-8915. [doi: 10.5194/acp-10-8899-2010]

Middleton, N. J., A. S. Goudie, 2001. Saharan dust: Sources and trajectories, Transactions of the Institute of British Geographers 26 (2), 165-181. [doi: 10.1111/1475-5661.00013]

Moore, J. K., O. Braucher, 2008. Sedimentary and mineral dust sources of dissolved iron to the world ocean, Biogeosciences 5 (3), 631-656. [doi: 10.5194/bg-5-631-2008]

Moreno, T., X. Querol, S. Castillo, A. Alastuey, E. Cuevas, L. Herrmann, M. Mounkaila, J. Elvira, W. Gibbons, 2006. Geochemical variations in aeolian mineral particles from the Sahara-Sahel Dust Corridor, Chemosphere 65 (2), 261-270. [doi: 10.1016/j.chemosphere.2006.02.052]

Muhs, D. R., 2013. The geologic records of dust in the Quaternary, Aeolian Research 9, 3-48. [doi: 10.1016/j.aeolia.2012.08.001]

Petit, J.-E., O. Favez, A. Albinet, F. Canonaco, 2017. A user-friendly tool for comprehensive evaluation of the geographical origins of atmospheric pollution: Wind and trajectory analyses, Environmental Modelling \& Software 88, 183-187. [doi: 10.1016/j.envsoft.2016.11.022]

Philippon, N., L. Jarlan, N. Martiny, P. Camberlin, E. Mougin, 2007. Characterization of the Interannual and Intraseasonal Variability of West African Vegetation between 1982 and 2002 by Means of NOAA AVHRR NDVI Data, Journal of Climate 20 (7), 1202-1218. [doi: 10.1175/JCLI4067.1]

Powell, C. F., A. R. Baker, T. D. Jickells, H. W. Bange, R. J. Chance, C. Yodle, 2015. Estimation of the Atmospheric Flux of Nutrients and Trace Metals to the Eastern Tropical North Atlantic Ocean, Journal of the Atmospheric Sciences 72 (10), 4029-4045. [doi: 10.1175/jas-d-15-0011.1]

Prian, J.-P., 2014. Phosphate Deposits of the Senegal-mauritania-guinea Basin (West Africa): A review, Procedia Engineering 83, 27-36. [doi: 10.1016/j.proeng.2014.09.008]

Prospero, J. M., 1999. Long-term measurements of the transport of African mineral dust to the southeastern United States: Implications for regional air quality, Journal of Geophysical Research: Atmospheres 104 (D13), 15917-15927. [doi: 10.1029/1999JD900072]

Prospero, J. M., F.-X. Collard, J. Molinié, A. Jeannot, 2014. Characterizing the annual cycle of African dust transport to the Caribbean Basin and South America and its impact on the environment and air quality: African dust transport to South America, Global Biogeochemical Cycles 28 (7), 757-773. [doi: 10.1002/2013GB004802]

Prospero, J. M., P. Ginoux, O. Torres, S. E. Nicholson, T. E. Gill, 2002. Environmental characterization of global sources of atmospheric soil dust identified with the NIMBUS 7 Total Ozone Mapping Spectrometer (TOMS) absorbing aerosol product, Reviews of Geophysics 40 (1), 1002. [doi: 10.1029/2000RG000095]

Prospero, J. M., R. A. Glaccum, R. T. Nees, 1981. Atmospheric transport of soil dust from Africa to South America, Nature 289 (5798), 570-572. [doi: 10.1038/289570a0]

Pye, K. (1987). Aeolian dust and dust deposits, Academic Press. London, 334p. 
Revel, M., C. Colin, S. Bernasconi, N. Combourieu-Nebout, E. Ducassou, F. E. Grousset, Y. Rolland, S. Migeon, D. Bosch, P. Brunet, Y. Zhao, J. Mascle, 2014. 21,000 Years of Ethiopian African monsoon variability recorded in sediments of the western Nile deep-sea fan, Regional Environmental Change 14 (5), 1685-1696. [doi: 10.1007/s10113-014-0588-x]

Ryan, W. B. F., Carbotte, S. M., J. O. Coplan, S. O'Hara, A. Melkonian, R. Arko, R. A. Weissel, V. Ferrini, A. Goodwillie, F. Nitsche, J. Bonczkowski, R. Zemsky, 2009. Global Multi-Resolution Topography synthesis, Geochemistry Geophyics Geosystems 10, Q03014. [doi: 10.1029/2008GC002332]

Schepanski, K., I. Tegen, M. C. Todd, B. Heinold, G. Bönisch, B. Laurent, A. Macke, 2009. Meteorological processes forcing Saharan dust emission inferred from MSG-SEVIRI observations of subdaily dust source activation and numerical models, Journal of Geophysical Research 114 (D10), D10201. [doi: 10.1029/2008JD010325]

Scheuvens, D., L. Schütz, K. Kandler, M. Ebert, S. Weinbruch, 2013. Bulk composition of northern African dust and its source sediments-A compilation, Earth-Science Reviews 116, 170-194. [doi: 10.1016/j.earscirev.2012.08.005]

Skonieczny, C., A. Bory, V. Bout-Roumazeilles, W. Abouchami, S. J. G. Galer, X. Crosta, A. Diallo, T. Ndiaye, 2013. A three-year time series of mineral dust deposits on the West African margin: Sedimentological and geochemical signatures and implications for interpretation of marine paleo- dust records, Earth and Planetary Science Letters 364, 145-156. [doi: 10.1016/j.epsl.2012.12.039]

Skonieczny, C., A. Bory, V. Bout-Roumazeilles, W. Abouchami, S. J. G. Galer, X. Crosta, J. B. Stuut, I. Meyer, I. Chiapello, T. Podvin, B. Chatenet, A. Diallo, T. Ndiaye, 2011. The 7-13 March 2006 major Saharan outbreak: Multiproxy characterization of mineral dust deposited on the West African margin, Journal of Geophysical Research 116, D18210. [doi: 10.1029/2011JD016173]

Skonieczny, C., D. McGee, G. Winckler, A. Bory, L. I. Bradtmiller, C. W. Kinsley, P. J. Polissar, R. De PolHolz, L. Rossignol, B. Malaizé, 2019. Monsoon-driven Saharan dust variability over the past 240,000 years, Science Advances 5, eaav1887. [doi: 10.1126/sciadv.aav1887]

Sokolik, I. N., D. M. Winker, G. Bergametti, D. A. Gillette, G. Carmichael, Y. J. Kaufman, L. Gomes, L. Schuetz, J. E. Penner, 2001. Introduction to special section: Outstanding problems in quantifying the radiative impacts of mineral dust, Journal of Geophysical Research: Atmospheres 106 (D16), 1801518027. [doi: 10.1029/2000JD900498]

Stein, A. F., R. R. Draxler, G. D. Rolph, B. J. B. Stunder, M. D. Cohen, F. Ngan, 2015. NOAA's HYSPLIT Atmospheric Transport and Dispersion Modeling System, Bulletin of the American Meteorological Society 96 (12), 2059-2077. [doi: 10.1175/BAMS-D-14-00110.1]

Stuut, J.-B., M. Zabel, V. Ratmeyer, P. Helkme, E. Schefuss, G. Lavik, R. Schneider, 2005. Provenance of present-day eolian dust collected off NW Africa, Journal of Geophysical Research 110 (D4), D04202. [doi: 10.1029/2004JD005161]

Tiedemann, R., M. Sarnthein, N. J. Shackleton, 1994. Astronomic timescale for the Pliocene Atlantic $\delta$ $18 \mathrm{O}$ and dust flux records of Ocean Drilling Program Site 659, Paleoceanography 9 (4), 619-638. doi: 10.1029/94PA00208] 
van der Does, M., G. J. A. Brummer, F. C. J. van Crimpen, L. F. Korte, N. M. Mahowald, U. Merkel, H. B. Yu, P. Zuidema, J. W. Stuut, 2020. Tropical Rains Controlling Deposition of Saharan Dust Across the North Atlantic Ocean, Geophysical Research Letters 47 (5). [doi: 10.1029/2019gl086867]

van der Does, M., P. Knippertz, P. Zschenderlein, R. G. Harrison, J. B. W. Stuut, 2018. The mysterious long-range transport of giant mineral dust particles, Science Advances 4 (12). [doi: 10.1126/sciadv.aau2768]

van der Does, M., L. F. Korte, C. I. Munday, G. J. A. Brummer, J. B. W. Stuut, 2016. Particle size traces modern Saharan dust transport and deposition across the equatorial North Atlantic, Atmospheric Chemistry and Physics 16 (21), 13697-13710. [doi: 10.5194/acp-16-13697-2016]

Varga, G., P. Dagsson- Walhauserová, F. Gresina, A. Helgadottir, 2021. Saharan dust and giant quartz particle transport towards Iceland, Scientific reports 11, 11891. [doi: 10.1038/s41598-021-91481-z]

Veselovskii, I., P. Goloub, T. Podvin, V. Bovchaliuk, Y. Derimian, P. Augustin, M. Fourmentin, D. Tanre, M. Korenskiy, D. N. Whiteman, A. Diallo, T. Ndiaye, A. Kolgotin, O. Dubovik, 2016. Retrieval of optical and physical properties of African dust from multiwavelength Raman lidar measurements during the SHADOW campaign in Senegal, Atmospheric Chemistry and Physics 16 (11), 7013-7028. [doi: 10.5194/acp-16-7013-2016]

Villeneuve, M., H. Bellon, A. El Archi, M. Sahabi, J.-P. Rehault, J.-L. Olivet, A. M. Aghzer, 2006. Événements panafricains dans I'Adrar Souttouf (Sahara marocain), Comptes Rendus Geoscience 338 (5), 359-367. [doi: 10.1016/j.crte.2006.02.008]

Westphal, D. L., C. A. Curtis, M. Liu, A. L. Walker, 2009. Operational aerosol and dust storm forecasting, IOP Conference Series: Earth and Environmental Science 7, 012007. [doi: 10.1088/1755$1307 / 7 / 1 / 012007]$

Yu, H., M. Chin, H. Bian, T. Yuan, J. M. Prospero, A. H. Omar, L. A. Remer, D. M. Winker, Y. Yang, Y. Zhang, Z. Zhang, 2015. Quantification of trans-Atlantic dust transport from seven-year (2007-2013) record of CALIPSO lidar measurements, Remote Sensing of Environment 159, 232-249. [doi: 10.1016/j.rse.2014.12.010]

Yu, Y., O. V. Kalashnikova, M. J. Garay, H. Lee, M. Notaro, J. R. Campbell, J. Marquis, P. Ginoux, G. S. Okin, 2020. Disproving the Bodele Depression as the Primary Source of Dust Fertilizing the Amazon Rainforest, Geophysical Research Letters 47 (13). [doi: 10.1029/2020gl088020]

Yu, H., Q. Tan, L. Zhou, Z. Y., H. Bian, M. Chin, C. L. Ryder, R. C. Levy, Y. Pradhan, Y. Shi, Q. Song, Z. Zhang, P. R. Colarco, D. Kim, L. A. Remer, T. Yuan, O. Mayol-Bracero, B. N. Holben, 2021. Observation and modeling of a historic African dust intrusion into the Caribbean Basin and the southern U.S. in June 2020, Atmospheric Chemistry and Physics., in review [doi: 10.5194/acp-2021- 73]

Zeegers, H., J.-C. Leprun, 1979. Evolution des concepts en altérologie tropicale et conséquences potentielles pour la prospection géochimique en Afrique occidentale soudano-sahélienne, Bulletin du BRGM II (2-3), 229-239. 
Figure 1: Total (dry plus wet) mineral dust deposition flux ( $<30 \mathrm{~mm}$ carbonate-free fraction; $\mathrm{mg} / \mathrm{m} 2 / \mathrm{d}$ ) and PM10 concentrations ( $\mu \mathrm{g} / \mathrm{m3}$; data available at http://www.lisa.u-pec.fr/SDT/) Mbour (Senegal) during the study period (March 2013 to February 2015). Wet seasons (shaded in blue) are defined as the period spanning the first and the last summer rain recorded at Mbour (1rst of July to the 18th of October in 2013 and 26th of May to the 10th of October in 2014). 


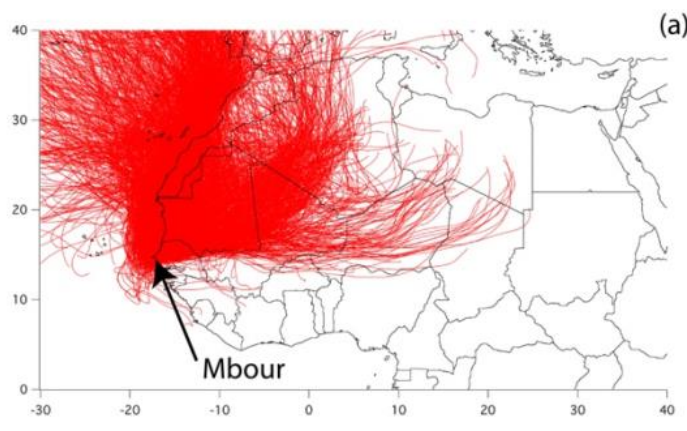

(a)

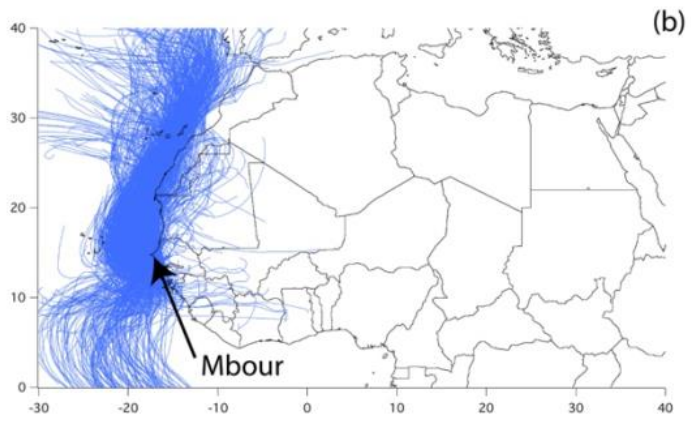

Figure 2: 5-day air mass back-trajectories ending at 250m at Mbour during [a] dry and [b] wet seasons. Back-trajectories were computed every 6 hours between March 2013 and February 2015 using the Hysplit dispersion Model developed by NOAA (Stein et al., 2015). 


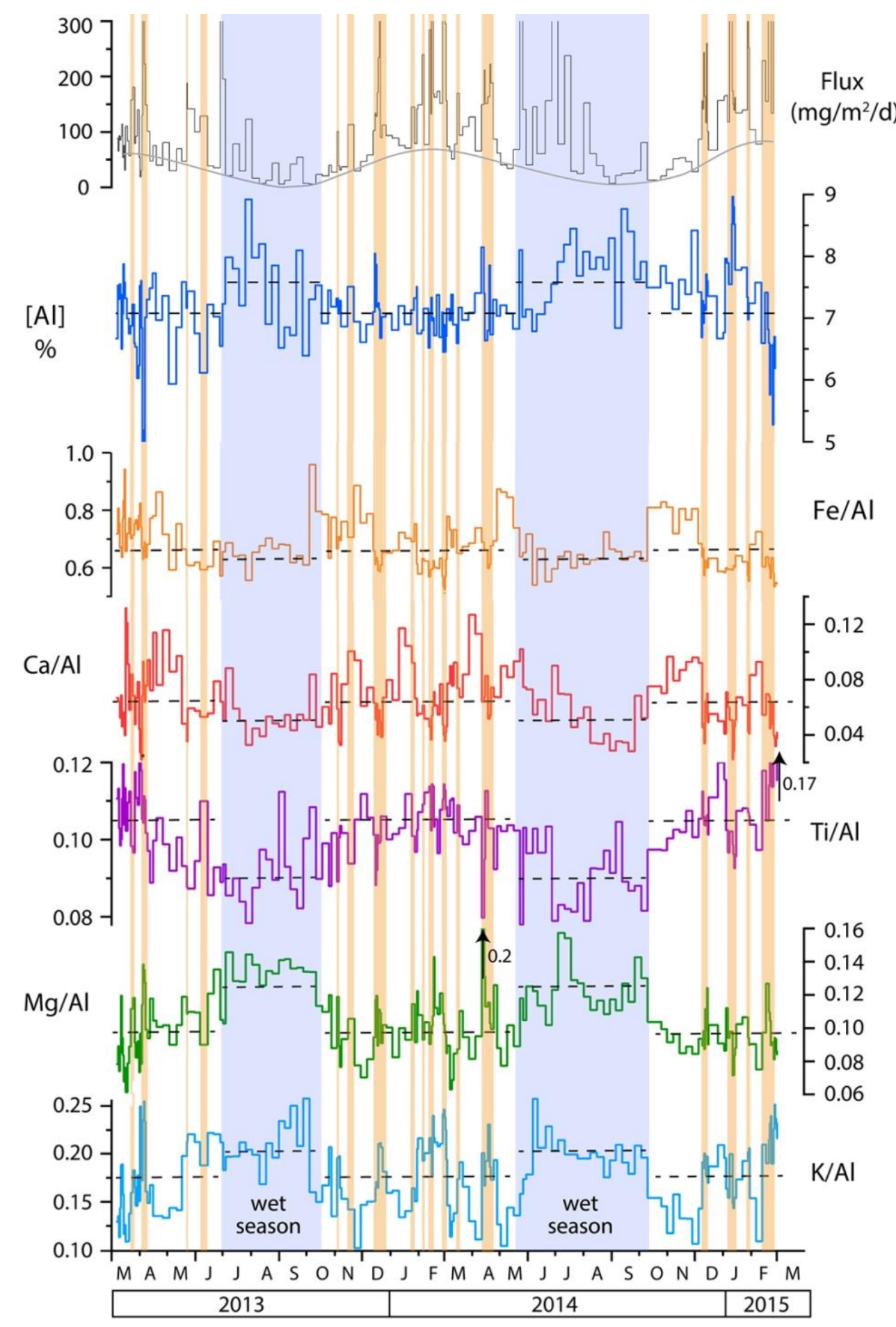

Figure 3: Total (dry plus wet) mineral dust deposition flux $(<30 \mu \mathrm{m}$ carbonate-free fraction) at Mbour (Senegal) during the study period (March 2013 to February 2015) as in Figure 1 (top panel), together with $\mathrm{Al}$ content and major element ratios ( $\mathrm{Fe} / \mathrm{Al}, \mathrm{Ca} / \mathrm{Al}, \mathrm{Ti} / \mathrm{Al}, \mathrm{Mg} / \mathrm{Al}$ and $\mathrm{K} / \mathrm{Al}$; lower six panels). Flux scale was truncated at $300 \mathrm{mg} / \mathrm{m} 2 / \mathrm{d}$ (see Figure 1 for full scale). Dust deposition flux background seasonal variability is underscored by the light grey curve. Periods shaded in blue correspond to wet seasons as in Figure 1 and areas highlighted in yellow to major deposition fluxes as defined in the text. Dashed lines in the elemental ratio panels indicate the simple arithmetic mean for each of the corresponding ratio during the overall dry and wet periods. 

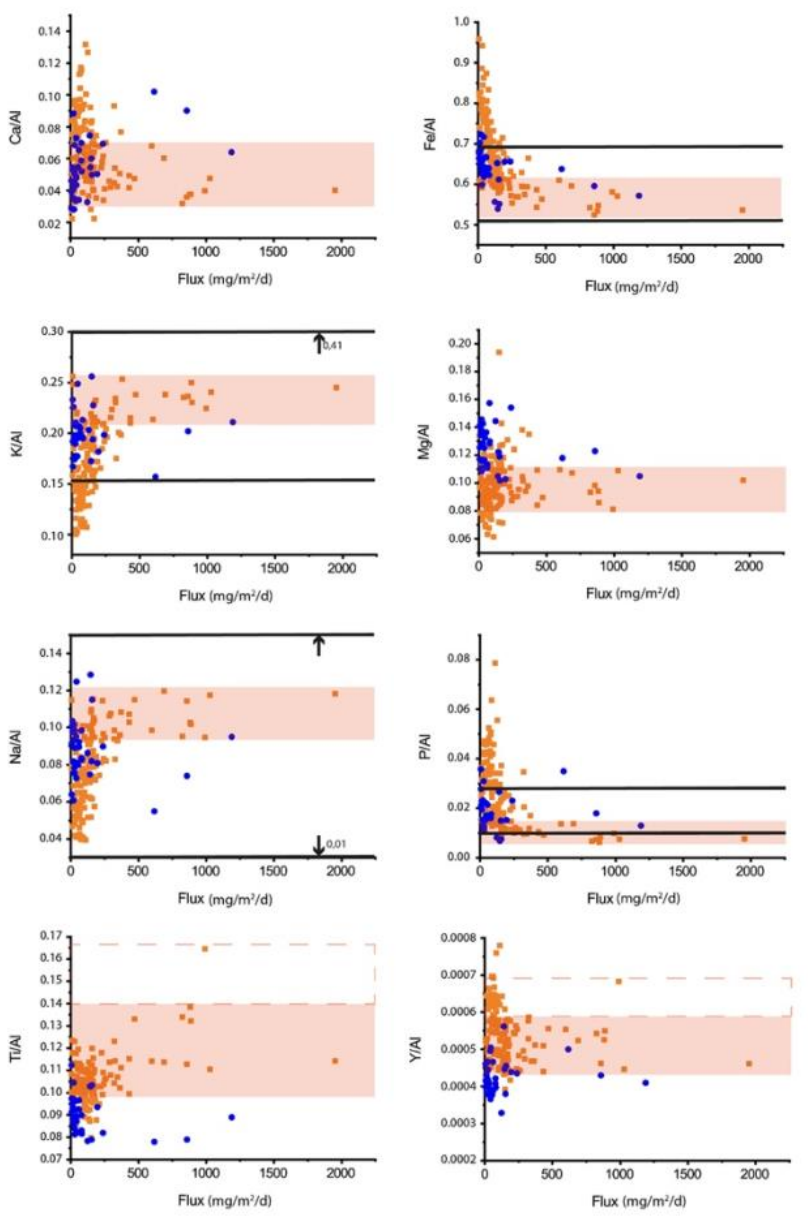

Figure 4: Elemental ratios (Ca/Al, $\mathrm{Fe} / \mathrm{Al}, \mathrm{K} / \mathrm{Al}, \mathrm{Mg} / \mathrm{Al}, \mathrm{Na} / \mathrm{Al}, \mathrm{P} / \mathrm{Al}, \mathrm{Ti} / \mathrm{Al}$, and $\mathrm{Y} / \mathrm{Al}$ ) in dust deposited during dry (orange squares) and wet (blue circles) seasons versus total deposition flux. Shaded areas highlight elemental ratios obtained for large deposition events recorded during the dry seasons (when flux is above $400 \mathrm{mg} / \mathrm{m} 2 / \mathrm{j}$ ); one outlier was excluded in the Ti/Al and Y/Al panels (dashed line boxes). Black lines indicate the ranges, when available, for West African dust compiled from the literature by Scheuvens et al. (2013). 
(a)

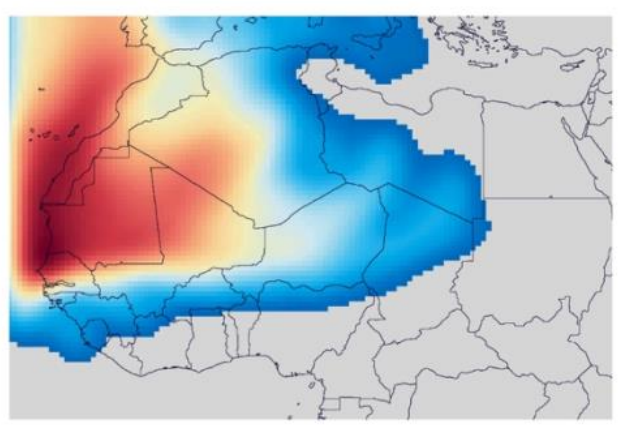

(b)

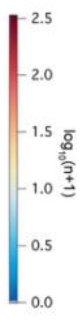

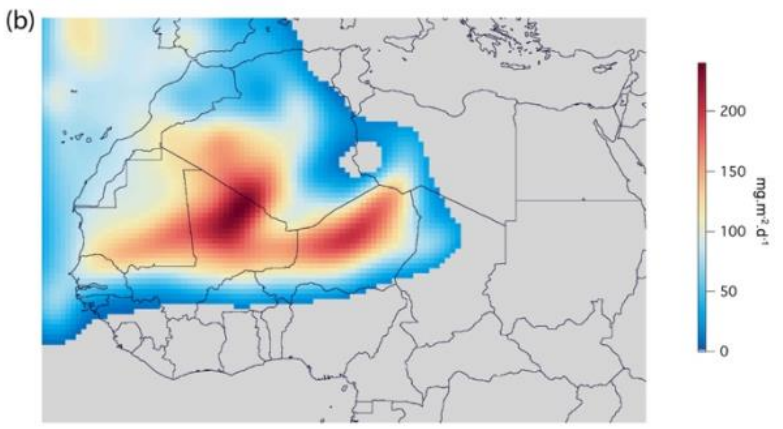

Figure 5: [a] Trajectory density during dry seasons; [b] identification of geographical areas associated with mass fluxes measured at Mbour. Both plots were made with Zefir (Petit et al., 2017). 

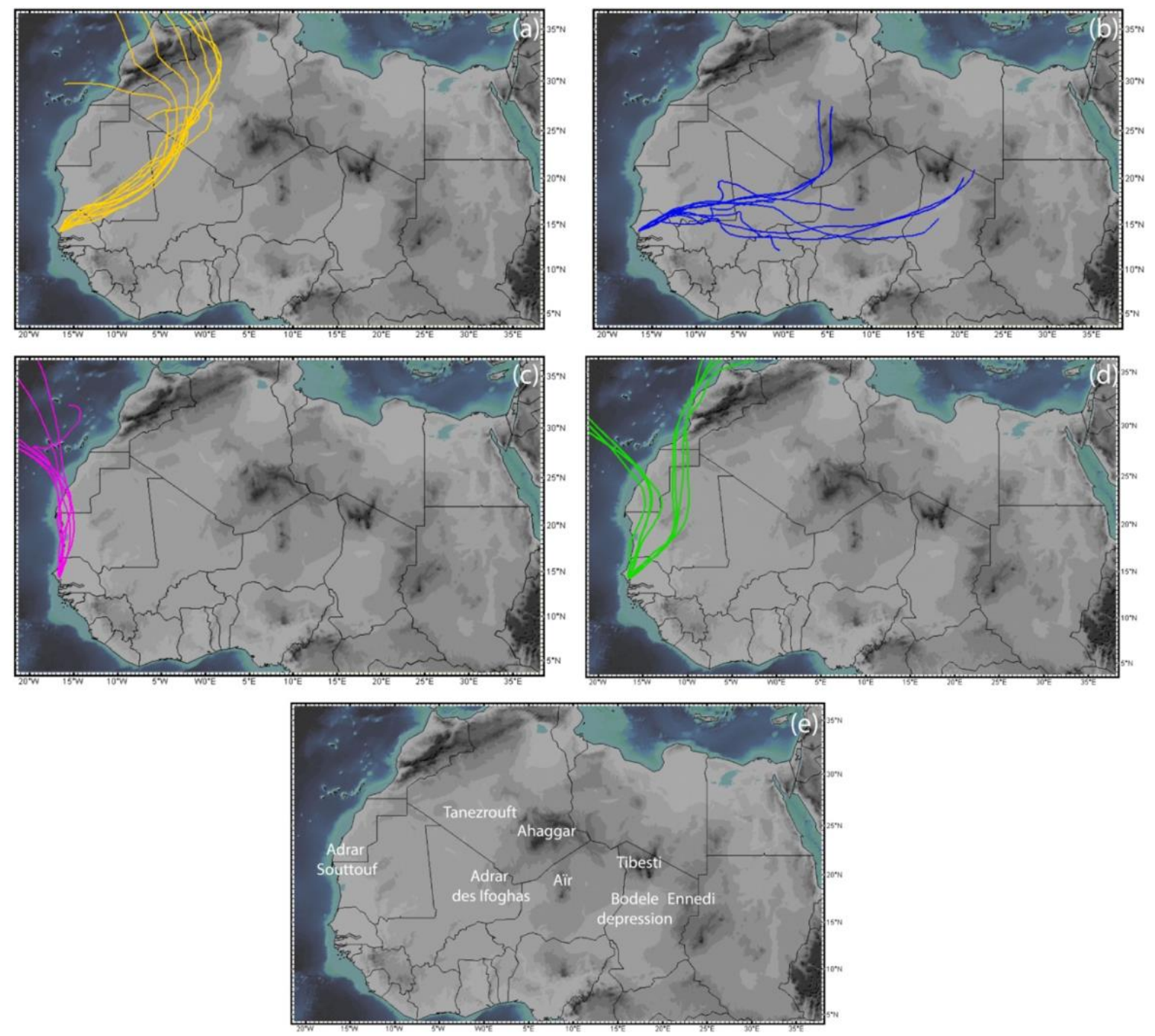

Figure 6: Typical examples of back-trajectories ending at 250m at Mbour and obtained for samples collected at a $\sim 24 \mathrm{~h}$ resolution from the Hysplit model for each of the main provenance sectors: [a] Algerian-Malian, [b] Sahelian, [c] Coastal and [d] Mauritanian. Some of the major geographical features of the region (Ahaggar, Adrar des Ifoghas, Air, Tibesti, and Ennedi moutains, Tanezrouft desert, Bodele depression, and Adrar Souttouf) are shown on panel [e]. Figures made with GeoMapApp (www.geomapapp.org; Ryan et al., 2009). 

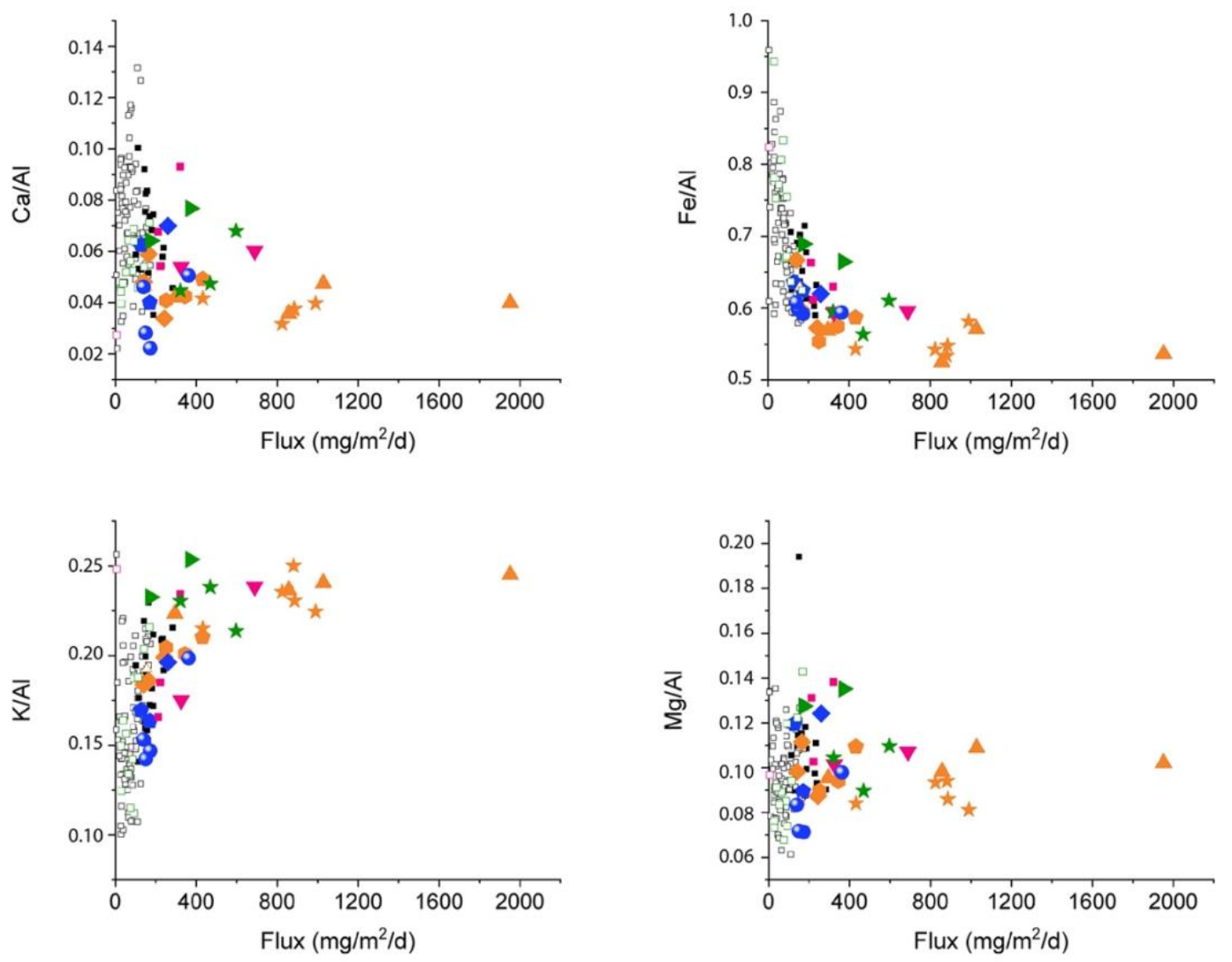

Figure 7: Elemental ratios (Ca/Al, Fe/Al, K/Al, Mg/Al) versus flux (mg.m-2.d-1) of deposited dust during dry seasons. Main deposition events (see text) are indicated by full symbols while "background" deposits are shown with empty symbols. Colour code provides indication regarding the sector of provenance for samples collected at a $\sim 24 \mathrm{~h}$ resolution: Algero-Malian sector (orange), Sahelian sector (blue), coastal sector (pink, and Mauritanian sector (green). Different symbol styles were attributed to each deposition event; consecutive samples (belonging to the same deposition event) are shown with the same symbol. Samples collected at lower (non daily) temporal resolution are shown by black full (major events) and empty (background flux) squares. 

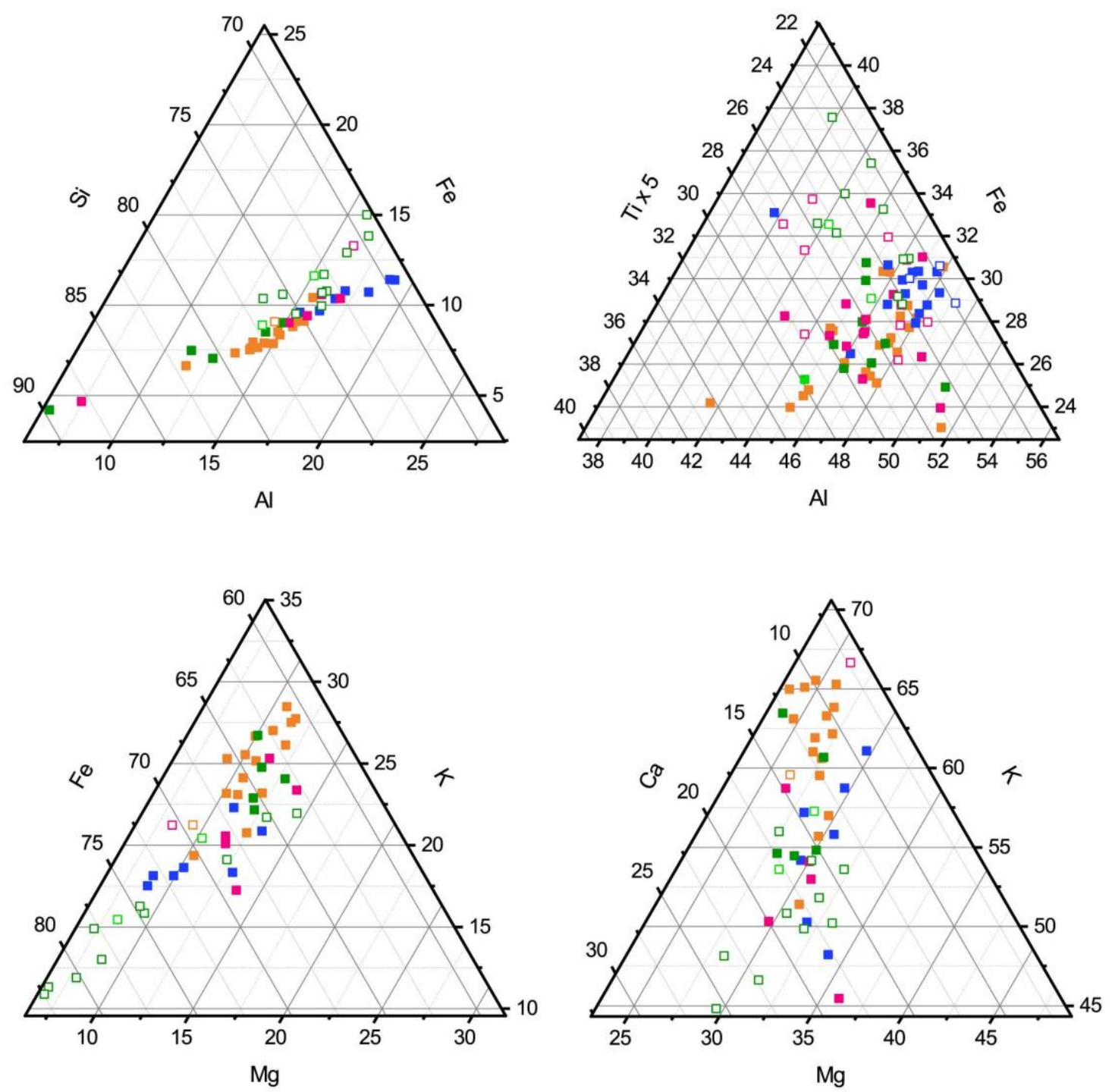

Figure 8: Ternary diagrams Al-Si-Fe, Al-Tix5-Fe, Mg-Fe-K, and Mg-Ca-K of samples collected at a 24h resolution. Empty squares are for background fluxes and full squares for dry season major events. Colors represent sectors of provenance (see figure 7). 